\title{
TITLE:
}

\section{Copepods Parasitic on Fishes of Western North Pacific}

$\operatorname{AUTHOR}(\mathrm{S})$ :

Ho, Ju-Shey; Ho, Ju-Shey; Kim, Il-Hoi

\section{CITATION:}

Ho, Ju-Shey ...[et al]. Copepods Parasitic on Fishes of Western North Pacific.

PUBLICATIONS OF THE SETO MARINE BIOLOGICAL LABORATORY 1996, 37(3-6): 275-303

ISSUE DATE:

1996-12-25

URL:

http://hdl.handle.net/2433/176263

RIGHT: 


\title{
Copepods Parasitic on Fishes of Western North Pacific
}

\author{
JU-SHEY HO \\ Department of Biological Sciences, California State University, \\ Long Beach, California 90840-3702, USA \\ and \\ IL-HOI KIM \\ Department of Biology, Kangreung National University, \\ Kangreung, Kangwon-do 210-702, Korea
}

\begin{abstract}
Eighteen species of copepods are reported from fishes of the western North Pacific, including the Bering Sea, Sea of Okhotsk and Sea of Japan. They belong to nine families (Caligidae, Chondracanthidae, Dichelesthiidae, Euryphoridae, Hatschekiidae, Pandaridae, Pennellidae, Lernaeopodidae, Naobranchiidae) in two orders (Poecilostomatoida, Siphonostomatoida) with two of them being new to science: Acanthochondria kajika n. sp. on Triglops scepticus Gilbert and Nectobrachia iceli $\mathrm{n}$. sp. on Icelus ochotensis Schmidt. Since many of the remaining 16 species are either new to this part of the Pacific Ocean or lacking good descriptions for reference, illustrations are given for poorly known species in addition to the new species. Lepeophtheirus watanabei Shiino, 1954 is proposed to be a synonym of $L$. bychowskyi Gusev, 1951.
\end{abstract}

\section{Introduction}

About 300 species of parasitic copepods have so far been reported from fishes of Japan. Most of them are known from fishes of the Sea of Japan, Inland Sea, and Pacific side of Honshu. From Hokkaido, the information of this group are astonishingly scanty. So far, only twelve species are known from the waters of Hokkaido: five species of Lepeophtheirus, and one species each of Acanthochondria, Chondracanthus, Clavella, Haemobaphes, Lophoura, Pennella and Salmincola (Wilson, 1917, 1919; Yamaguti, 1939; Shiino, 1954, 1955a, 1959a, 1959b; Nagasawa, 1984, 1985; Nagasawa \& Maruyama, 1987).

Markevitch \& Titar (1978) listed 48 species of parasitic copepods from fishes of the Sea of Okhotsk, 24 of them occur also in the Bering Sea. Thirty of these 48 species were recorded from the same waters by Gusev (1951), Markevich (1956) and Kabata \& Gusev (1966), thus, 18 species listed by Markevich \& Titar (1978) were new to the Bering Sea and/or Sea of Okhotsk. However, regrettably, the hosts were not given by them. Recently, Kazachenko (1995) added one more species to these parts of the western North Pacific.

In the 80's, Dr. Kazuya Nagasawa collected copepod parasites of marine fishes landed at Kushiro, Hokkaido. In addition, he collected them from fishes caught in the Sea of Okhotsk and Bering Sea and kept in the Laboratory of Marine Zoology, Faculty of Fisheries, Hokkaido University. Dr. Nagasawa entrusted us with his valuable collections. In total, 18 species in nine families of two orders of Copepoda were identified. Two of them are new to science and a great majority of the remaining 16 species are new to these waters.

In this paper, a full set of illustrations is given of those imperfectly known or questionable species, in addition to the two new species. 


\section{Description of Species}

Order Poecilostomatoida Thorell, 1859

Family Chondracanthidae Milne Edwards, 1840

\section{Acanthochondria priacanthi Shiino, 1964}

Material examined. Two ovigerous females, each carrying a male, attached to inner side of operculum at the base of gill arch of Arctoscopus japonicus (Steindachner) collected off Kushiro on 18 October 1984.

Remarks

This species was recently redescribed by Ho \& Kim (1995) based on the present material. It was the second report of this species. A. priacanthi is known only from Japan.

\section{Acanthochondria kajika, new species}

(Figs. 1-2)

Material examined. Eight ovigerous females and 7 males (each attached to a female) on inner side of operculum of 8 Triglops scepticus Gilbert, collected from Bering Sea (57 $\left.38^{\prime} \mathrm{N} 173^{\circ} 43^{\prime} \mathrm{W}\right)$ on 12 July 1978 and kept in Faculty of Fisheries, Hokkaido University. One female specimen (carrying a male) was selected for the holotype and deposited, together with five paratypes (each carrying a male), in the U.S. National Museum of Natural History, Smithsonian Institution in Washington, D.C.

Female

Body (Fig. 1A-C) greatly swollen, $7.74 \mathrm{~mm}$ long and $2.76 \mathrm{~mm}$ wide. Head slightly longer than wide, with swollen oral area. Neck region distinct, consisting of narrow first pediger and much wider second pediger. Trunk greatly swollen, with slight lateral indentation and a pair of moderately long posterolateral processes. Abdomen (Fig. 1D) elliptical, carrying caudal rami in its midventral surface. Caudal ramus (Fig. $1 E$ ) armed with 3 setae and 3 knobs in basal region; terminal portion spine-like. Egg sac longer than half of body length.

Antennule (Fig. 1F) filiform; armature formula 1-1-2-2-8. Antenna (Fig. 1G) 2 -segmented; terminal segment a curved claw with sharply pointed tip. Labrum (Fig. $1 \mathrm{H}$ ) with fine spinules on posterior margin. Mandible (Fig. 1I) 2-segmented, with 33 teeth on convex side and 30 teeth on concave side of terminal blade. Paragnath (Fig. 1J) a spinulose lobe. Maxillule (Fig. 1K) with a patch of spinules on anterior surface and 2 unequal terminal setae. Maxilla (Fig. 1L) 2-segmented; first segment greatly enlarged but unarmed; terminal segment with 1 large and 1 small setae in basal region and a row of 11 teeth on terminal process. Maxilliped (Fig. 2A) 3-segmented; first segment largest but unarmed; second segment squarish, with spinulose lobe distal to spinulated medial surface; terminal claw with subterminal tooth. Leg 1 (Fig. 2B) smaller than leg 2 (Fig. 2C), both carrying an outer seta on protopod and spinules on bluntly pointed surface of both rami.

Male

Body (Fig. 2D) $500 \mu \mathrm{m}$ long, with swollen cephalothorax containing first pediger. Genital ridges on ventral surface of genital complex distinct (Fig. 2E), carrying a seta. Caudal ramus (Fig. 2E) with spinules on terminal portion and 4 setae and 1 small knob on basal portion.

Antennule (Fig. 2F) filiform; formula of armature 1-1-2-1-8. Antenna (Fig. 2G) strongly recurved hook with an inner seta and a small outer knob tipped with 2 setules. Labrum (Fig. $2 \mathrm{H}$ ) with lateral protuberance in addition to fine spinules on posterior margin. Mandible (Fig. 2I) with 14 teeth on convex side and 14 teeth on concave side of terminal blade. Paragnath 


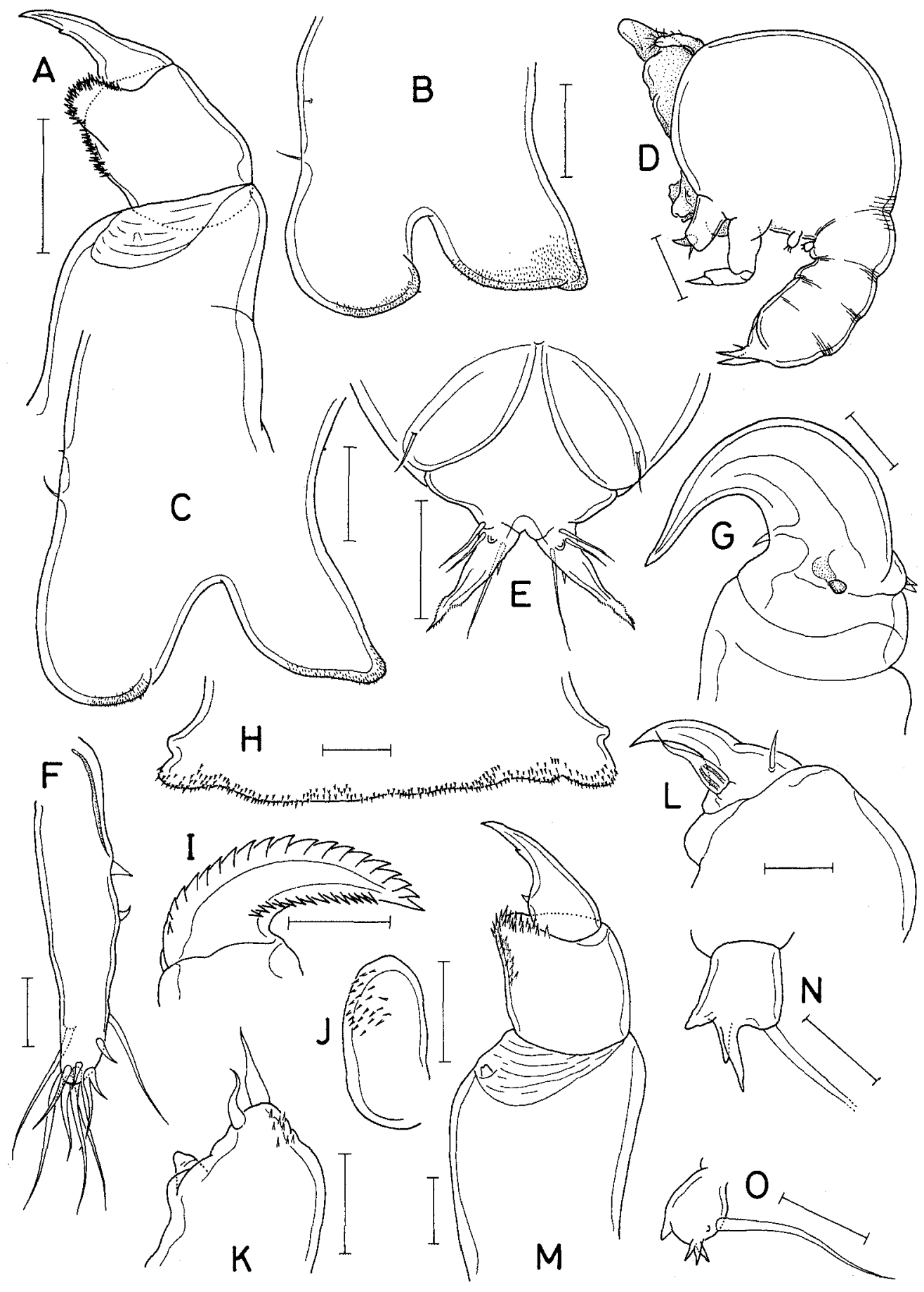

Fig. 1. Acanthochondria kajika, new species, female. A. Habitus, dorsal; B. Same, ventral; C. Contracted individual, dorsal; D. Abdomen, ventral; E. Caudal ramus; F. Antennule; G. Antenna; H. Labrum; I. Mandible; J. Paragnath; K. Maxillule; L. Maxilla. Scales: $1 \mathrm{~mm}$ in A, B, C; $0.1 \mathrm{~mm}$ in $\mathrm{D}, \mathrm{F}-\mathrm{H} ; 0.05 \mathrm{~mm}$ in $\mathrm{E}, \mathrm{I}-\mathrm{K}$. 


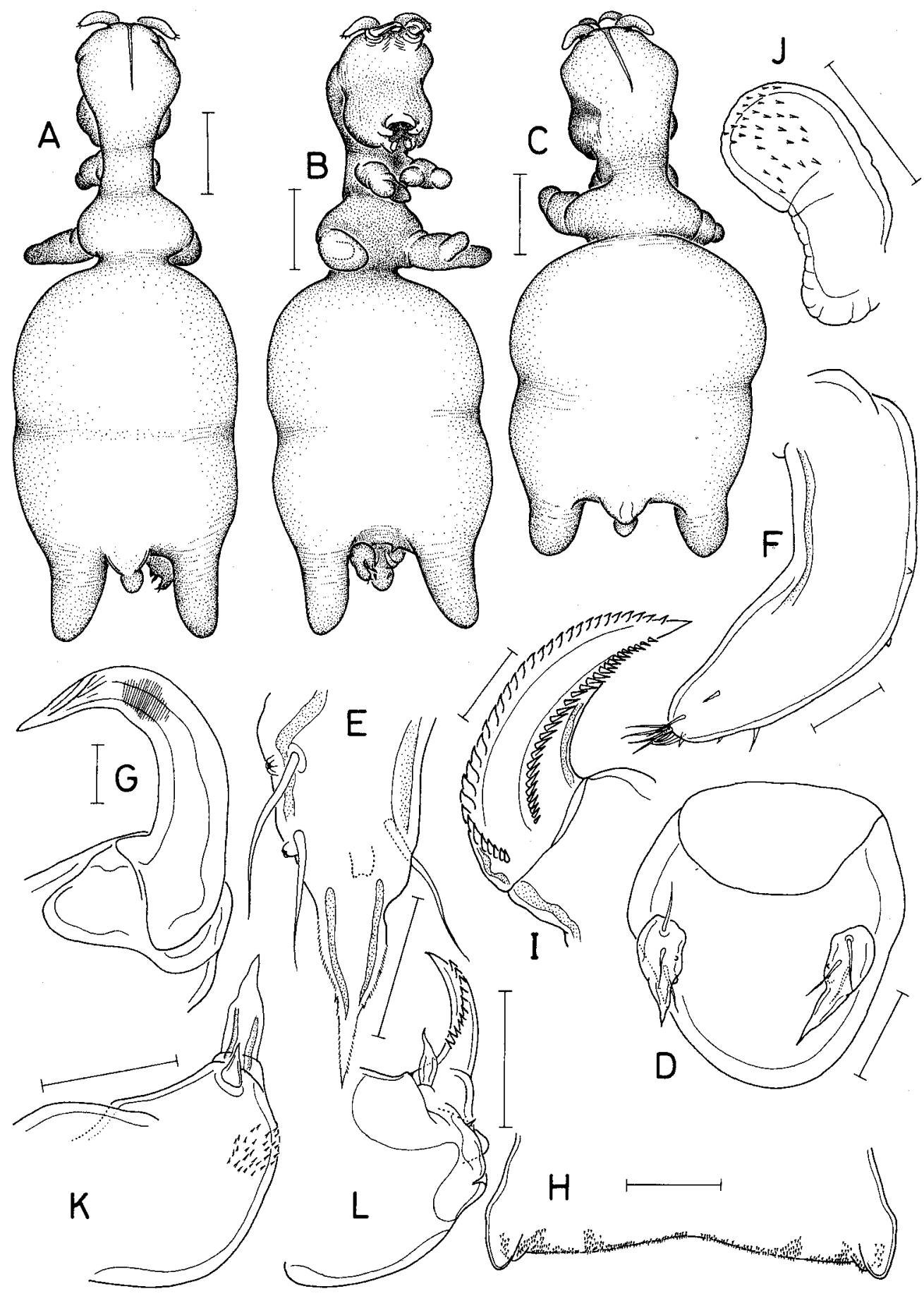

Fig. 2. Acanthochondria kajika, new species. Female: A. Maxilliped; B. Leg 1; C. Leg 2. Male: D. Habitus, lateral; E. Posterior portion of body, ventral; F. Antennule; G. Antenna; H. Labrum; I. Mandible; J. Paragnath; K. Maxillule; L. Maxilla; M. Maxilliped; N. Leg 1; O. Leg 2. Scales: $0.1 \mathrm{~mm}$ in $\mathrm{A}, \mathrm{D} ; 0.2 \mathrm{~mm}$ in $\mathrm{B}, \mathrm{C} ; 0.05 \mathrm{~mm}$ in $\mathrm{E} ; 0.02 \mathrm{~mm}$ in $\mathrm{F}-\mathrm{O}$. 
(Fig. 2J) a spinulose lobe. Maxillule (Fig. 2K) with a basal protuberance in addition to 2 terminal unequal setae. Maxilla (Fig. 2L) different from that of female in lacking teeth on terminal process. Maxilliped (Fig. 2M) generally as in female. Both leg 1 (Fig. 2N) and leg 2 (Fig. 2O) with long outer seta on protopod and endopod represented by a process. Exopod of leg 1 bipartite, but that of leg 2 tripartite.

\section{Etymology}

The family name of the host fish (Cottidae) is "kajika" in Japanese, from which the name was taken.

\section{Remarks}

Following the key to species of Acanthochondria (Ho \& Kim, 1995), this species shares the features with $A$. fissicauda Shiino, 1955. However, $A$. kajika is distinct from the latter. The major differences are found in the structure of the head, trunk, and maxilla in the female and antenna and legs 1 and 2 in the male.

\section{Acanthochondria sp.}

(Figs. 3-5)

Material examined. Three adult and one juvenile females with each carrying a pygmy male found on inner side of operculum of Triglops pingeli pingeli Reinhardt, collected from Bering Sea (date unknown) and kept in Faculty of Fisheries, Hokkaido University.

Female

Body (Fig. 3A,B) with slightly indented lateral surface in trunk, $5.80 \mathrm{~mm}$ long and 1.70 mm wide. Genitoabdomen (Fig. 3C) carrying a pair of vermiform processes adjacent to trunk and a seta in egg sac attachment area. Abdomen elliptical. Caudal ramus (Fig. 3D) armed with 3 setae and 1 knob in basal region.

Antennule (Fig. 3E) slightly inflated basally; formula of armature 1-1-1-2-9. Antenna (Fig. 3F) 2-segmented; terminal segment a curved claw with sharply pointed tip. Labrum (Fig. $3 \mathrm{G}$ ) with fine spinules on posterior margin and a protuberance on lateral side. Mandible (Fig. $3 \mathrm{H}) 2$-segmented; with 33 teeth on convex side and 23 teeth on concave side. Paragnath (Fig. 3I) bilobated with spinulose inner lobe. Maxillule (Fig. 3J) with blunt basal lobe and 2 unequal terminal setae. Maxilla (Fig. 3K) 2-segmented; terminal segment with 1 large and 1 small setae in basal region and a row of 4 teeth on terminal process.

Maxilliped (Fig. 4A) 3-segmented; first segment largest and unarmed; second segment protruded distally into a spinulose lobe; terminal segment strongly curved claw. Leg 1 (Fig. 4B) smaller than leg 2 (Fig. 4C), both covered with spinules on rami.

Male

Body (Fig. 4D) $650 \mu \mathrm{m}$ long, with swollen cephalothorax containing first pediger. Genital ridges on ventral surface of genital complex distinct (Fig. 4E). Caudal ramus (Fig. 4E) with 4 setae and 1 small knob on basal portion.

Antennule (Fig. 4F) filiform; formula of armature 1-1-2-1-8. Antenna (Fig. 4G) strongly recurved hook with an inner seta. Mandible (Fig. 4I) with 16 teeth on convex side and 12 teeth on concave side. Paragnath (Fig. 4J) spinulose lobe. Maxillule (Fig. 4K) essentially as in female. Maxille (Fig. 4L) different from that of female in lacking teeth on terminal process. Maxilliped (Fig. 4M) different from that of female in armature of terminal segment. Leg 1 (Fig. 4N) and leg 2 (Fig. 4O) similarly constructed, with long outer seta on protopod and tripartite exopod.

Juvenile female

Body (Figs 5A,B) with head wider than trunk, $2.53 \mathrm{~mm}$ long and $0.79 \mathrm{~mm}$ wide. 


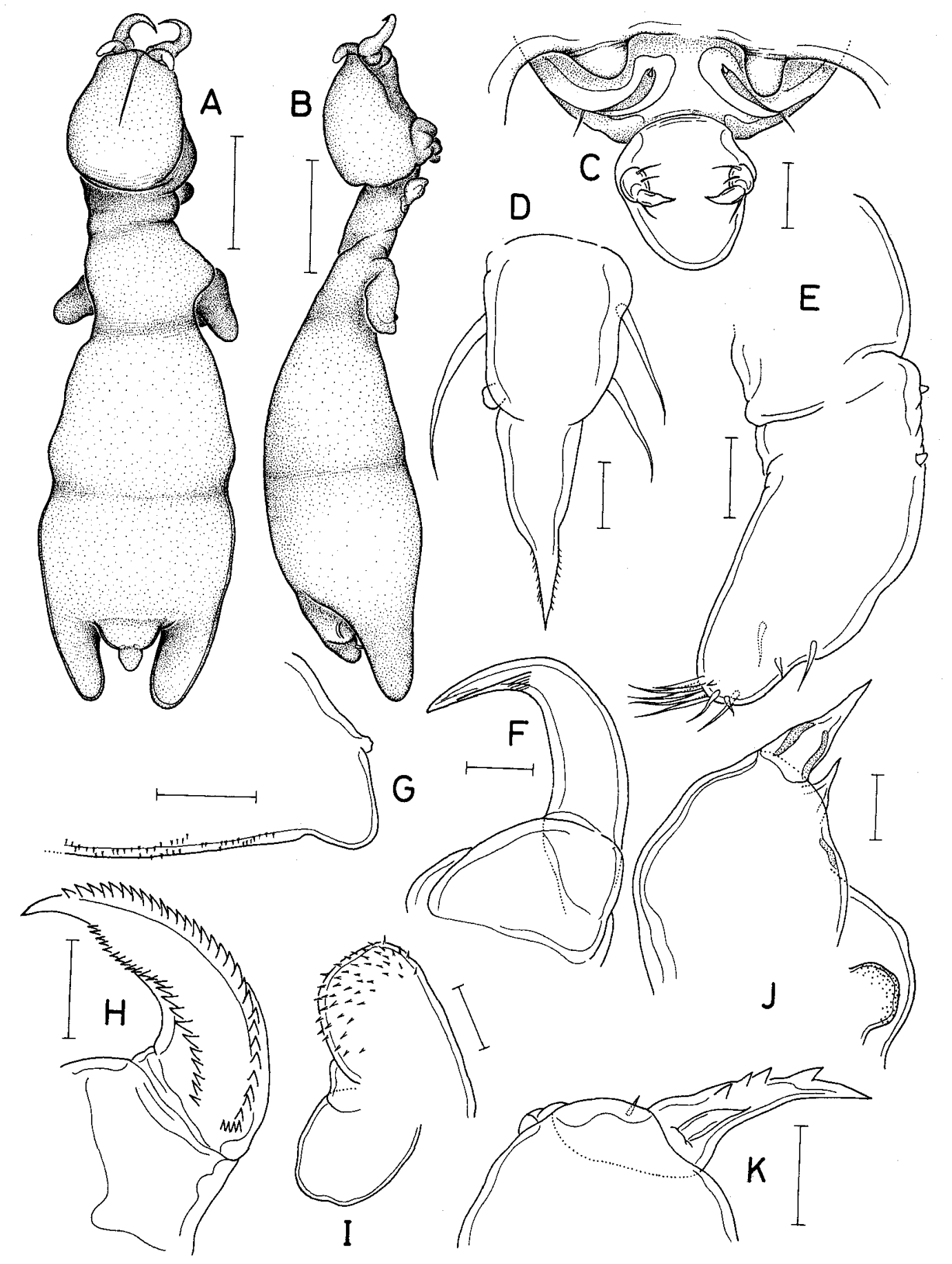

Fig. 3. Acanthochondria sp., female. A. Habitus, dorsal; B. Same, lateral; C. Genito-abdomen, ventral; D. Caudal ramus; E. Antennule; F. Antenna; G. Labrum (left half), ventral; H. Mandible; I. Paragnath; J. Maxillule; K. Maxilla. Scales: $1 \mathrm{~mm}$ in A, B; $0.1 \mathrm{~mm}$ in B, F; $0.05 \mathrm{~mm}$ in E, G, K; 0.02 $\mathrm{mm}$ in $\mathrm{D}, \mathrm{I}, \mathrm{J}$. 


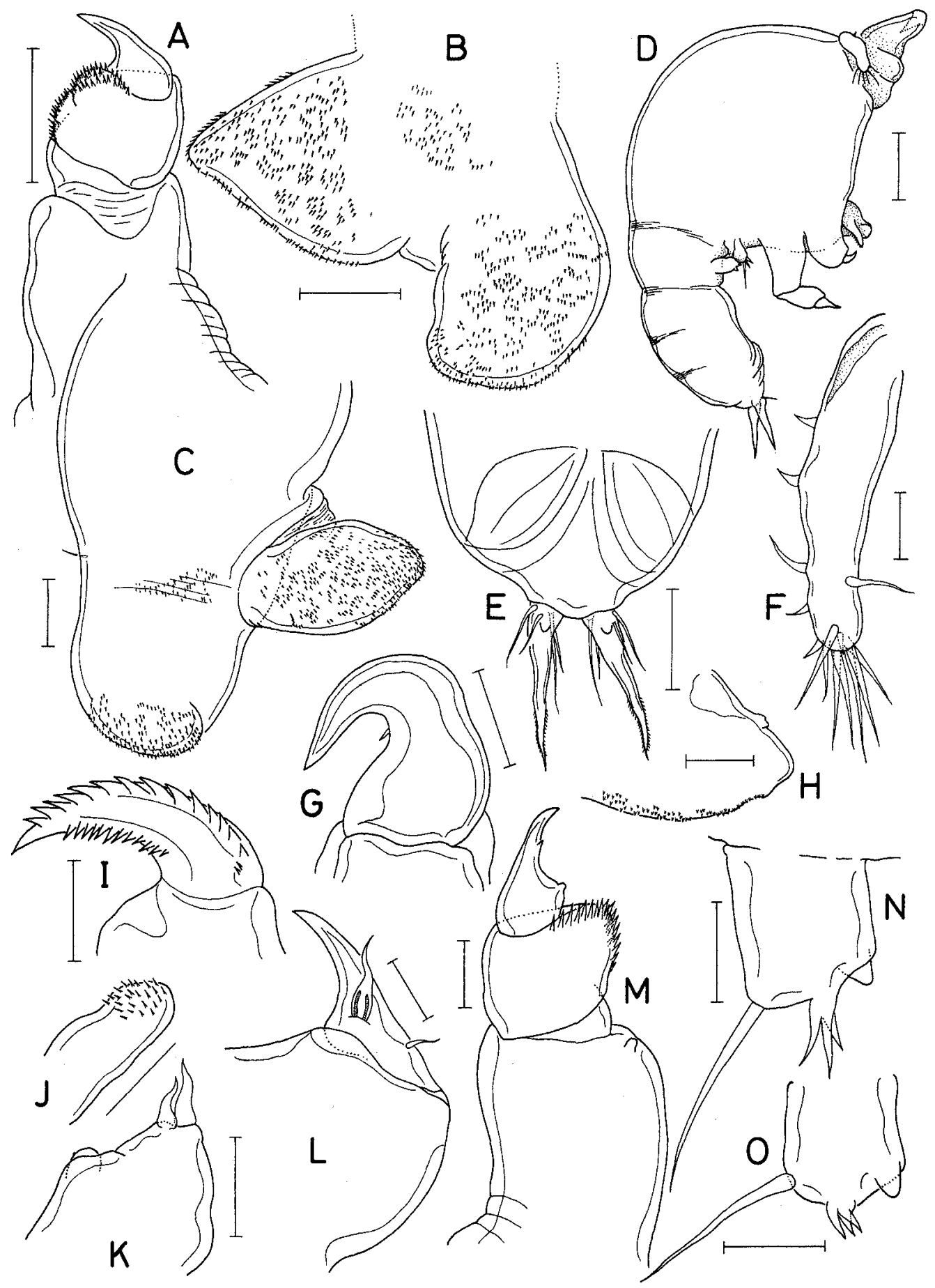

Fig. 4. Acanthochondria sp. Female: A. Maxilliped; B. Leg 1; C. Leg 2. Male: D. Habitus, lateral; E. Posterior portion of body, ventral; F. Antennule; G. Antenna; H. Labrum (left half), ventral; I. Mandible; J. Paragnath; K. Maxillule; L. Maxilla; M. Maxilliped; N. Leg 1; O. Leg 2. Scales: $0.1 \mathrm{~mm}$ in $\mathrm{A}-\mathrm{D} ; 0.05 \mathrm{~mm}$ in $\mathrm{E}, \mathrm{G} ; 0.02 \mathrm{~mm}$ in $\mathrm{F}, \mathrm{H}-\mathrm{O}$. 


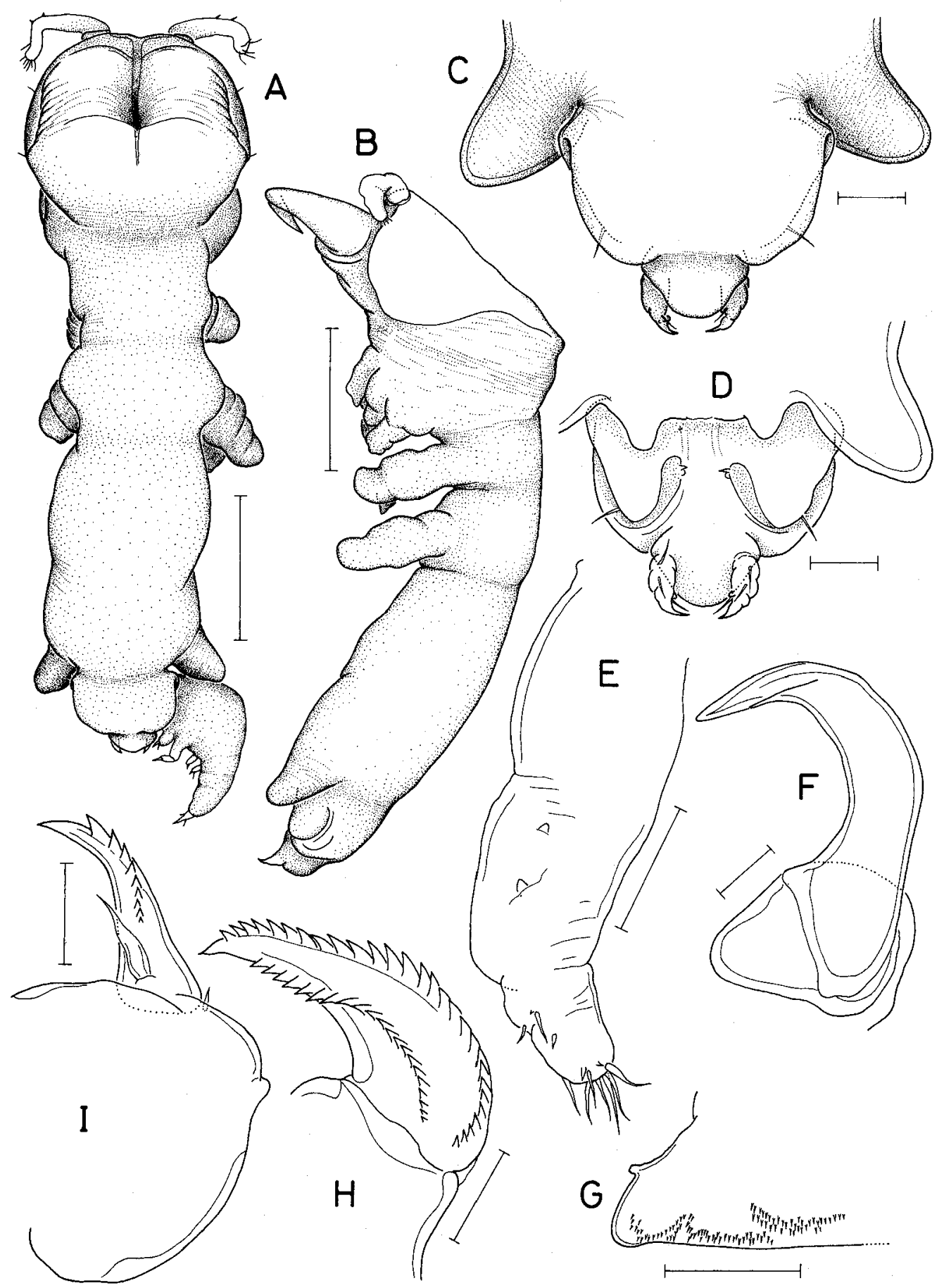

Fig. 5. Acanthochondria sp., juvenile female. A. Habitus, dorsal; B. Same, lateral; C. Posterior portion of body, dorsal; D. Genito-abomen, ventral; E. Antennule; F. Antenna; G. Labrum (right half), ventral; H. Mandible; I. Maxilla. Scales: $0.5 \mathrm{~mm}$ in A, B; $0.1 \mathrm{~mm}$ in C-G; $0.05 \mathrm{~mm}$ in $\mathrm{H}$, J. 
Posterolateral processes large and divergent (Fig. 5C). Genitoabdomen (Fig. 5D) bearing a pair of vermiform processes adjacent to trunk and a seta in egg sac attachment area. Antennule (Fig. 5E), antenna (Fig. 5F), labrum (Fig. 5G), mandible (Fig. 5H), paragnath, maxillule and maxilliped generally as in adult female. Maxilla (Fig. 5I) different from adult female in possessing more teeth on terminal process. Both legs 1 and 2 covered with more spinules than in adult.

Remarks

According to Ho \& Kim's (1995) recent review on the species of Acanthochondria, the number of teeth on the terminal process of maxilla is species specific. From the above description it is clear that there is discrepancy in terms of this armature between the adult and the juvenile female. However, due to the limited number of available specimens, it is impossible to determine which one has the abnormality of this character state. Thus, the species is left unnamed.

Following Ho \& Kim's (1955) key to 48 species of Acanthochondria, this species shares some features with $A$. vancouverensis Kabata, 1984. However, this species differs from the latter in the structure of the head, antennule and maxilla. Although they are parasitic on sculpins, their microhabitat on the host is different, while $A$. vancouverensis is a parasite of nasal capsule, the present unnamed species is a parasite of branchial cavity.

\section{Chondracanthus yanezi Atria, 1980}

Material examined. Three ovigerous females, each carrying a male, on inner side of operculum of 3 Psychrolutes phrictus Stein \& Bond taken off Kushiro; 10 ovigerous females and 8 males (each attached to a female) recovered from inner side of operculum of 4 Malacocottus zonurus Bean collected from Bering Sea (date unknown) and kept in Faculty of Fisheries, Hokkaido Univer. sity.

Remarks

This species was found from a psychrolutid taken off Chile (Atria, 1980) and then reported only from another psychrolutid taken off California (Ho, 1982). The specimens from the Bering Sea have smaller lateral processes on the trunk; otherwise, they fit well with the redescription given by $\mathrm{Ho}_{\mathrm{O}}(1982)$.

\section{Chondracanthus irregularis Fraser, 1920}

Material examined. A single female attached to inner side of operculum of a Myoxocephalus polyacanthocephalus (Pallas) collected off Kushiro, Hokkaido on 13 October 1983.

Remarks

This is the first record of $C$. irregularis from the Pacific coast of Hokkaido. The specimen fits well with the description given by Kabata (1968) and Gusev (1951; as C. dogieli). According to Ho (1991), this species is known only from the sculpins (Cottidae) of the North Pacific. It is found on the same host species in the estern North Pacific off the coast of British Columbia, Canada.

Order Siphonostomatoida Thorell, 1859

Family Caligidae Burmeister, 1835

\section{Lepeophtheirus elegans Gusev, 1951}

(Figs. 6-7)

Material examined. One hundred and ninty-eight females and 49 males on body surface of Pholidapus 


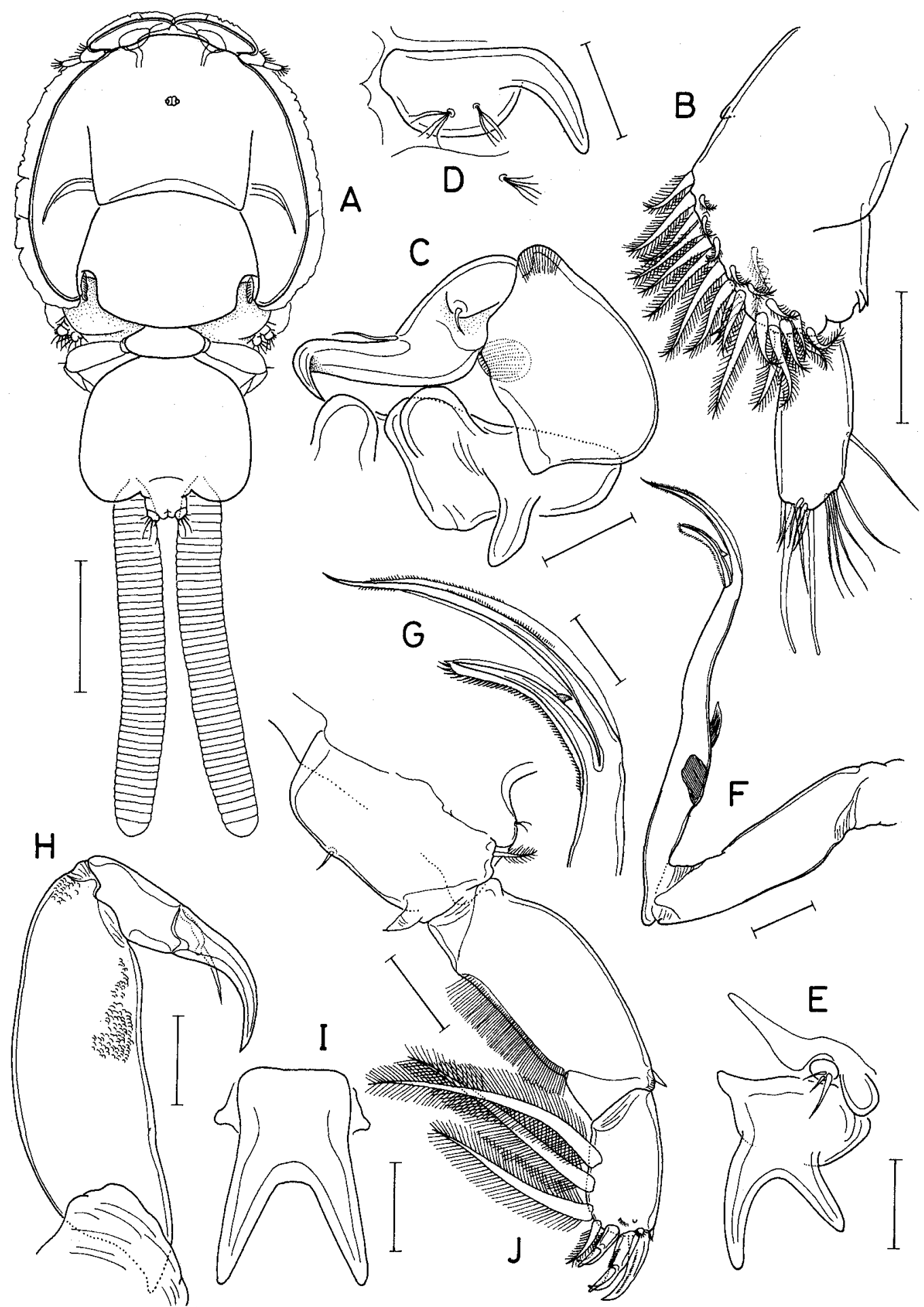

Fig. 6. Lepeophtheirus elegans Gusev, female. A. Habitus, dorsal; B. Antennule; C. Antenna; D. Postantennary process; E. Maxillule; F. Maxilla; G. Tip of maxilla; H. Maxilliped; I. Sternal furca; J. Leg 1. Scales: $1 \mathrm{~mm}$ in A; $0.1 \mathrm{~mm}$ in B-F, H-J; $0.05 \mathrm{~mm}$ in G. 


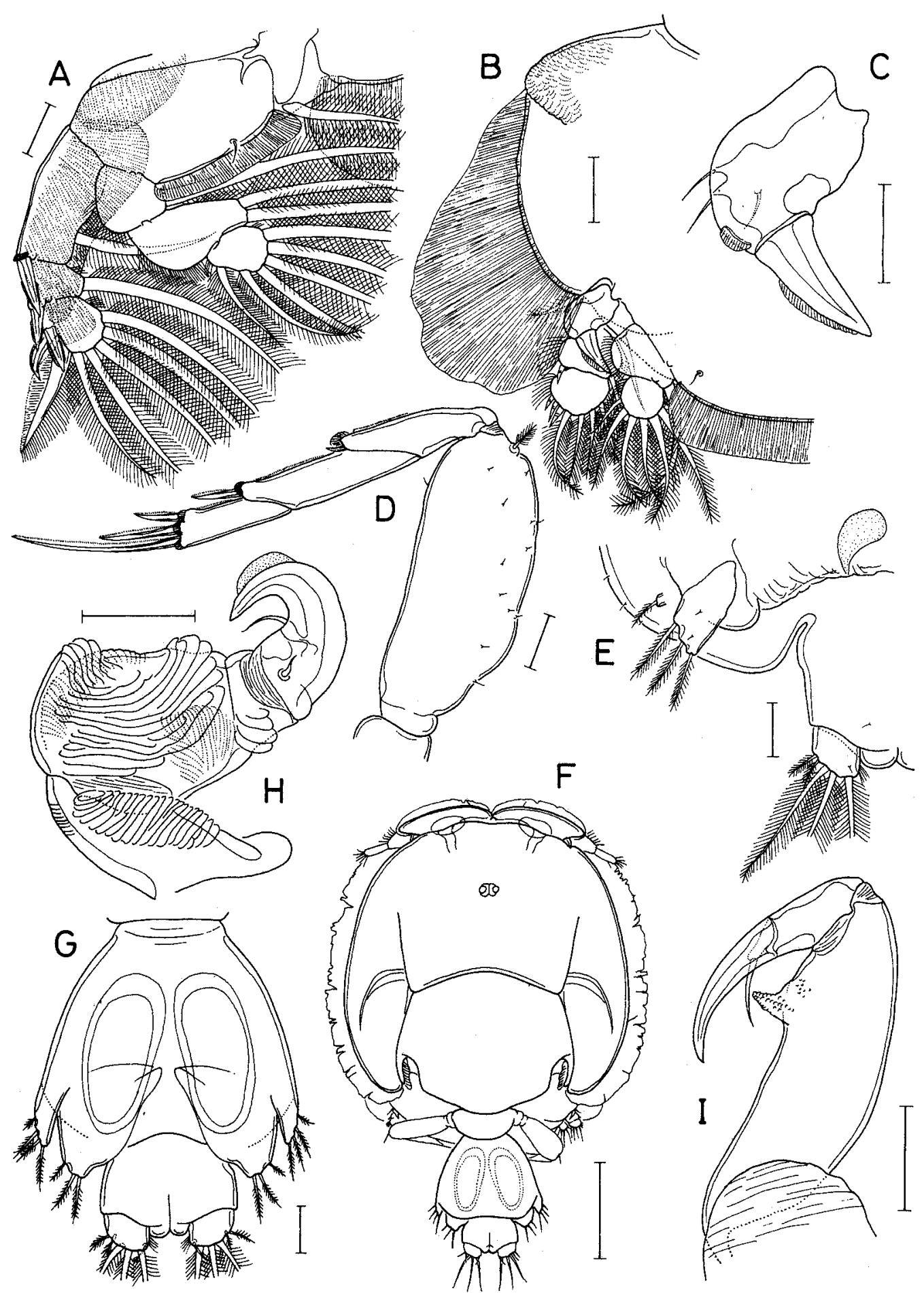

Fig. 7. Lepeophtheirus elegans Gusev. Female: A. Leg 2; B. Leg 3; C. Proximal segment of Leg 3 exopod; D. Leg 4; E. Leg 5 and caudal ramus. Male: F. Habitus, dorsal; G. Genital double somites and abdomen, ventral; H. Antenna; I. Maxilliped. Scales: $0.1 \mathrm{~mm}$ in A, B, D, E, G-I; $0.05 \mathrm{~mm}$ in C; $0.5 \mathrm{~mm}$ in $\mathrm{F}$. 
dybowskii (Steindachner) collected from Notsuke Bay in eastern Hokkaido on 21 October, 1983. Remarks

This species is known so far only from the pholid and cottid fishes of the Sea of Japan (Gusev, 1951). Features of the specimens examined coincide with Gusev's (1951) original description, except for fine structures of several appendages.

While the female body (Fig. 6A), antenna (Fig. 6C), postantennary process (Fig. 6D), maxillule (Fig. 6E), maxilliped (Fig. 6H), sternal furca (Fig. 6I), leg 2 (Fig. 7A), leg 3 (Fig. 7B, C) and leg 4 (Fig. 7D) are identical with the original description, some fine structures of the female appendages are overlooked by Gusev (1951): the antennule (Fig. 6B) is armed with 25 plumose and 2 simple setae on the basal segment and 12 simple setae and 2 aesthetes on the terminal segment; the maxilla (Fig. 6F,G) bears a small hooklet on outer margin of canna; the middle two terminal spines on the exopod of leg 1 (Fig. $6 \mathrm{~J}$ ) carry subterminal, secondary process; and leg 5 (Fig. 7E) is represented by a small knob tipped with a small, plumose seta and a larger lamella carrying 3 plumose setae.

Features of the male (Fig. 7F-I) are identical with the original description.

\section{Lepeophtheirus bychowskyi Gusev, 1951}

(Figs. 8-9)

Material examined. Seventy-nine females, 10 males and 58 chalimus larvae on body surface of 3 Myoxocephalus stelleri Tilesius collected from Bering Sea (date unknown) and kept in Faculty of Fisheries, Hokkaido University.

\section{Remarks}

$L$. bychowski is known from $M$. stelleri in the Sea of Japan. Features of the present specimens agreed with Gusev's original description. However, there are fine structural differences.

The differences are found mainly in the following three appendages: the female antennule (Fig. $8 \mathrm{C}$ ) is armed with 25 plumose and 2 simple setae on the basal segment and 2 simple setae and 2 aesthetes on the distal segment; the middle two terminal spines on the exopod of leg 1 (Fig. 8J) carry secondary, subterminal process; and the male antenna (Fig. $9 \mathrm{~F}$ ) is tipped with 3 hooks.

In checking on the copepod parasites of cottids, it wsa discovered unexpectedly that Lepeophtheirus watanabei Shiino, 1954 reported from "M. raninus J. \& S." (Shiino, 1954a) taken at Tosima, Hokkaido is identifiable with the present species. Thus, it is proposed that L. watanabei Shiino, 1954 should be relegated to the junior synonym of $L$. bychowskyi Gusev, 1951.

Family Euryphoridae Wilson, 1905

Gloiopotes huttoni (Thomson, 1889)

\section{[= Gloiopotes longicaudatus (Marukawa, 1925) $]$}

Material examined. Four females on body surface of a Xiphias gladius Linnaeus caught off Kamaishi, Iwate Prefecture on 13 August 1982.

Remarks

In Japan, this species of copepod parasites has been reported mainly from the marlin off the Pacific coast of Honshu (Yamaguti, 1936; Shiino, 1954b, 1957). The present finding extends the northern limit in Japan from Kesennuma, Miyagi (Shiino, 1957) to Kamaishi, Iwate. This species has been redescribed several times in the past (Yamaguti, 1936; Shiino, 


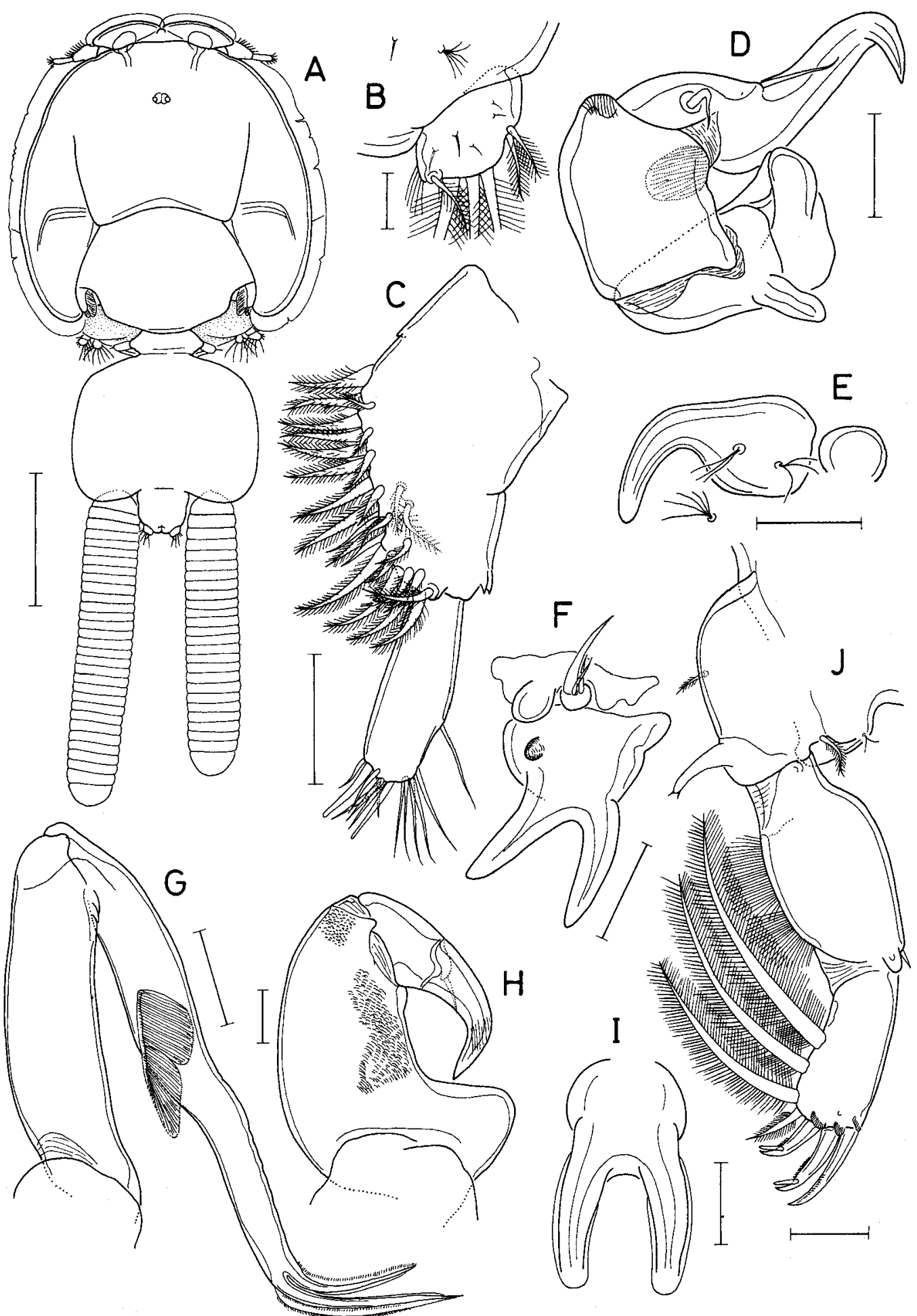

Fig. 8. Lepeophtheirus bychowskyi Gusev. Female: A. Habitus, dorsal; B. Caudal ramus; C. Antennule; D. Antenna; E. Postantennal process; F. Maxillule; G. Maxilla; H. Maxilliped; I. Sternal furca; J. Leg 1. Scales: $1 \mathrm{~mm}$ in A; $0.05 \mathrm{~mm}$ in $\mathrm{B} ; 0.1 \mathrm{~mm}$ in $\mathrm{C}-\mathrm{J}$. 


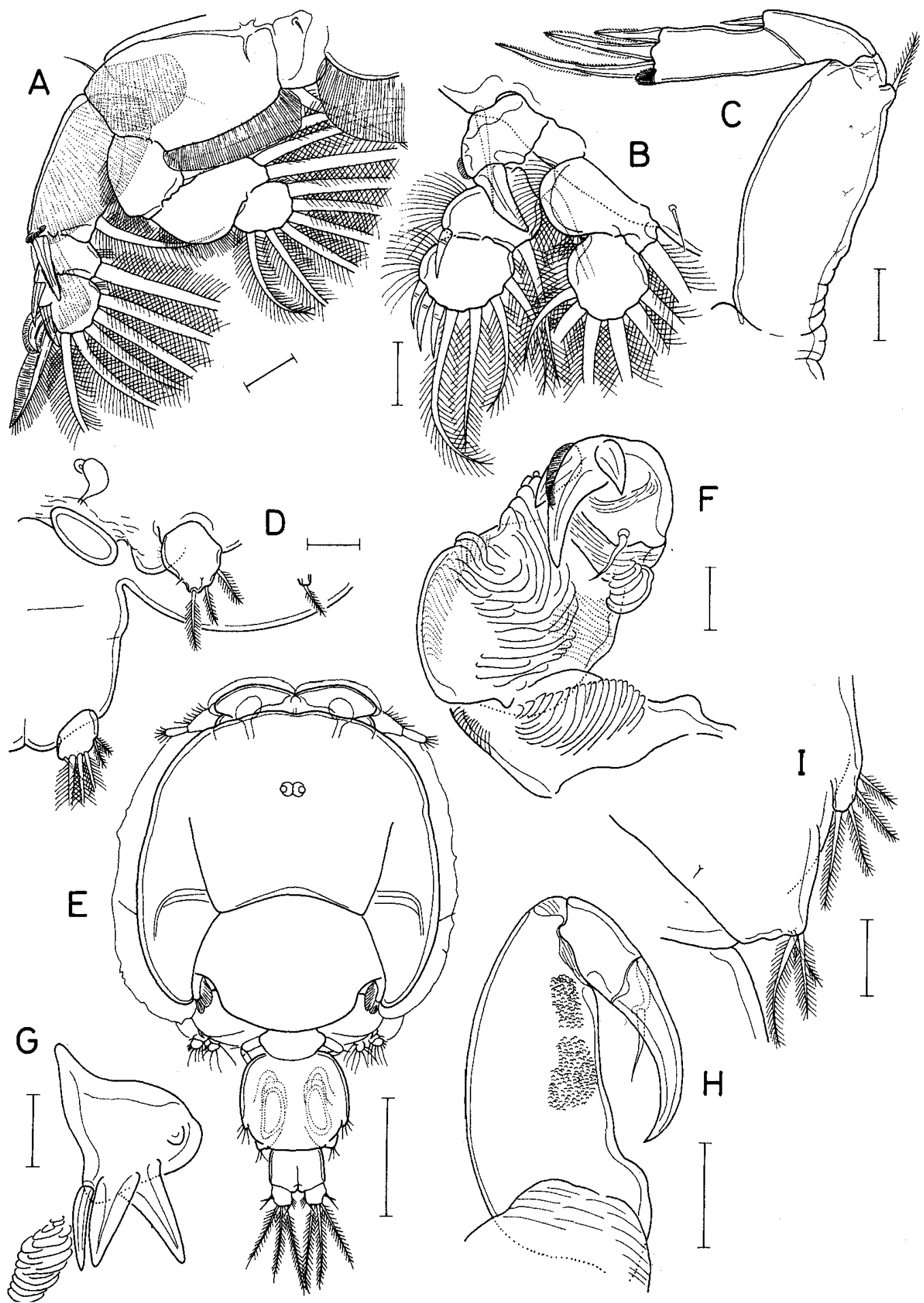

Fig. 9. Lepeophtheirus bychowskyi Gusev. Female: A. Leg 2; B. Leg 3; C. Leg 4; D. Leg 5 and caudal ramus. Male: E. Habitus, dorsal; F. Antenna; G. Maxillule; H. Maxilliped; I. Legs 5 and 6 . Scales: $0.1 \mathrm{~mm}$ in $\mathrm{A}, \mathrm{D}, \mathrm{H}, \mathrm{I} ; 0.05 \mathrm{~mm}$ in B. C. F. G; $0.5 \mathrm{~mm}$ in $\mathrm{E}$. 
1954b; Hewitt, 1964; Cressey, 1967a; Lewis, 1967), thus, there is no need for us to add another set of illustrations.

Family Pandaridae Milne Edwards, 1840

\section{Echthrogaleus coleoptratus (Guérin-Méneville, 1837)}

Material examined. Four females on dorsal fin of a Lamna ditropis Hubbs et Follet caught at $53^{\circ} 43^{\prime} \mathrm{N}$ $179^{\circ} 31^{\prime} \mathrm{E}$ in Bering Sea on 8 July 1981.

Remarks

This species is a common parasite of sharks living in the Pacific, Atlantic and Indian Oceans. From the Bering Sea, it has been recorded by Wilson (1907) on an unnamed shark caught near Unalaska, Alaska. Due to its common occurrence in many parts of the world, $E$. coleoptratus has been redescribed several times in the past. For a complete list of synonyms of this species see Kabata (1979a: 220).

\section{Ecthrogaleus denticulatus Smith, 1874}

(Figs. 10-11)

Material examined. Eight females on pectoral and caudal fins of a Carcharodon carcharias (Linnaeus) collected off Todohokke, Hokkaido on 31 May 1985.

Remarks

Cressey (1967b) reported $E$. denticulatus from two far apart seas, western North Atlantic and Indian Ocean, and Pillai (1985) called it cosmopolitan in distribution. In Japan, this is the second report of $E$. denticulatus. The first report was made more than forty years ago by Shiino (1954c) from Isurus glauca landed at Owase market in Mie. Since some discrepancies were detected between Shiino's (1954c) description and our specimens, full set of drawings made from Dr. Nagasawa's collection is included for close comparison.

While the body (Fig. 10A), antennule (Fig. 10C,D), antenna (Fig. 10E), maxillule (Fig. 10F), maxilla (Fig. 10G), leg 1 (Fig. 11A), leg 2 (Fig. 11B), leg 3 (Fig. 11C), leg 4 (Fig. 11D) and leg 5 (Fig. 11E) show no significant difference, the maxilliped of the Hokkaidoan specimens (Fig. $10 \mathrm{H}, \mathrm{I})$ is quite different in having its terminal claw in the form of an asymmetrically bifid process, not a strongly curved, pointed hook as described by Shiino (1954c). Since the maxilliped of our material fits well with the most recent and best redescription of $E$. denticulatus ever made (Pillai, 1985), we consider our Hokkaidoan specimens are $E$. denticulatus.

Cressey (1967b) considered that the male of E. denticulatus (Shiino, 1954c) was Pandarus satyrus Dana. Pillai (1985) relegated E. pellucidus Shiino, 1963 to a synonym of $E$. denticulatus.

Through the courtesy of Dr. Ichiro Takeuchi of the Otsuchi Marine Research Center, recently, one of us (JSH) was able to examine a large patch of copepods taken from the ventral surface of a great white shark (Carcharodon carcharias, $498 \mathrm{~cm}$ in total length) caught at the entrance of the Otsuchi Bay, Iwate. It is interesting to point out that five species of copepods were identified from this patch of copepods, with 8 Pandarus satyrus Dana, 15 Dinemoura latifolia Steenstrup \& Lütken, 21 Dinemoura producta (Müller), 28 Echthrogaleus coleopterus (Guérin-Ménevill), and 32 E. denticulatus. 

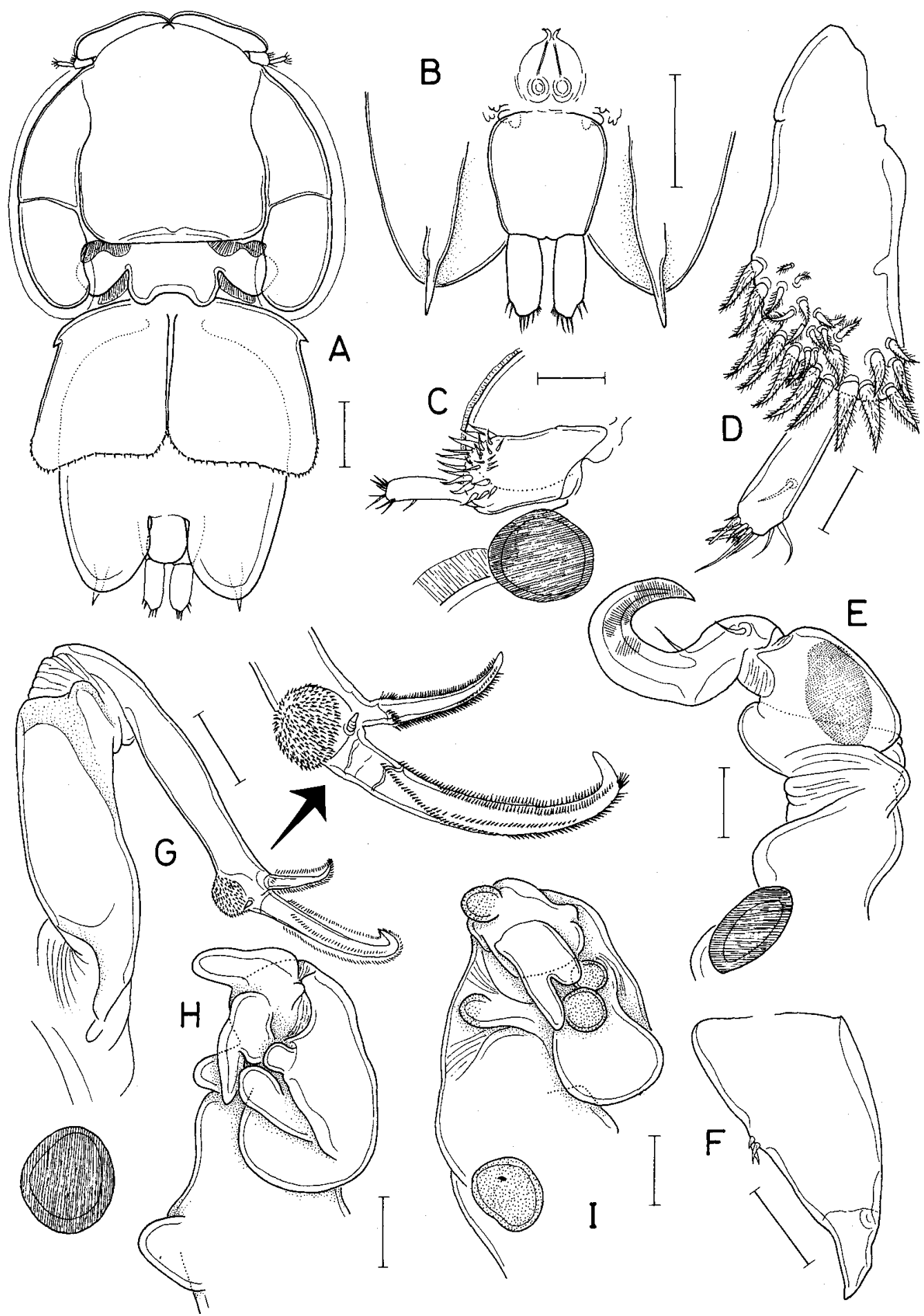

Fig. 10. Echthrogaleus denticulatus Smith, female. A. Habitus, dorsal; B. Posterior portion of body, ventral; C. Antennal region; D. Antennule; E. Antenna; F. Maxillule; G. Maxilla; H. Maxilliped, anterior; I. Same, ventral. Scales: $1 \mathrm{~mm}$ in A, B; $0.2 \mathrm{~mm}$ in C, E, G-I; $0.1 \mathrm{~mm}$ in D, F, 


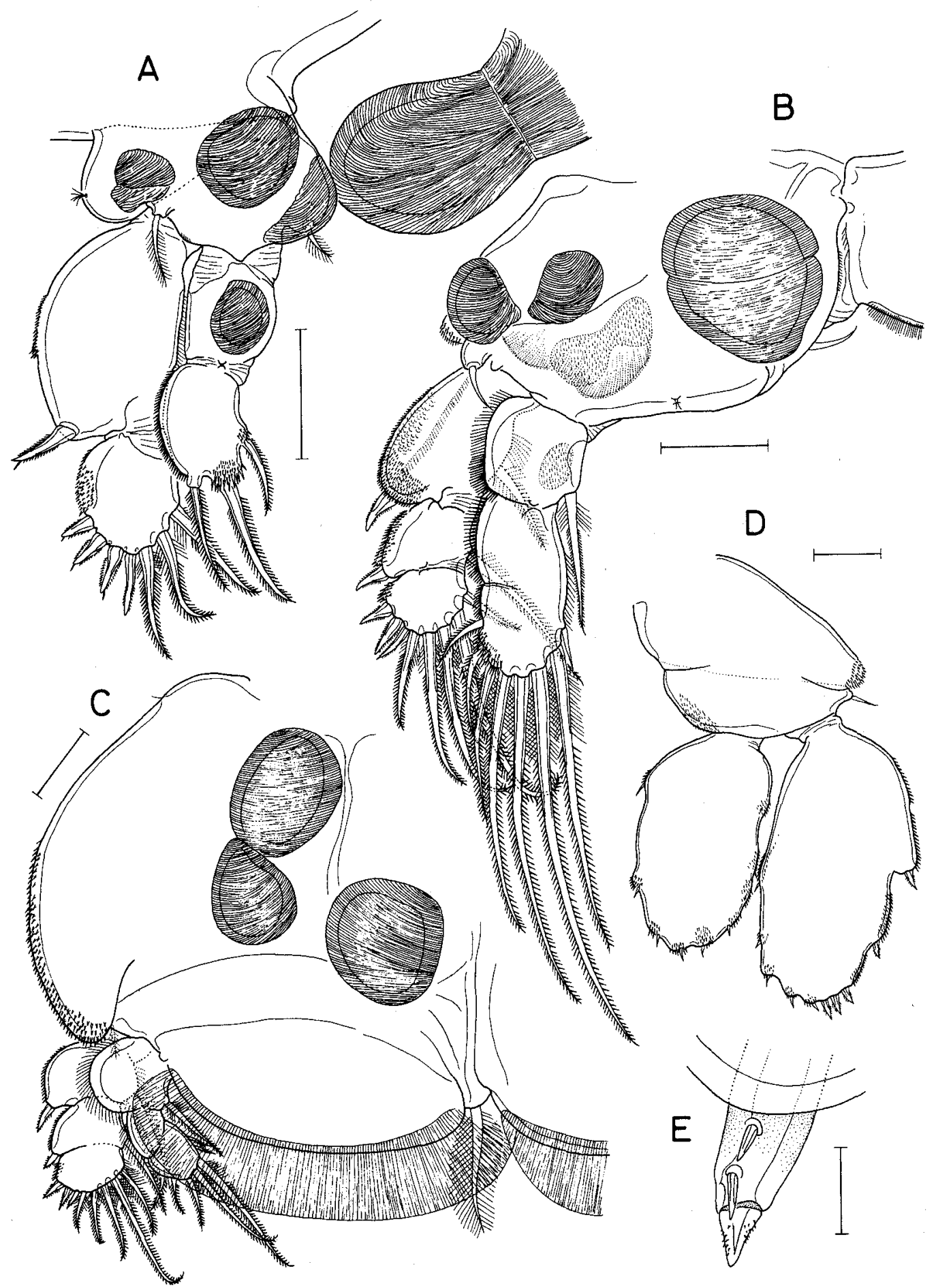

Fig. 11. Echthrogaleus denticulatus Smith, female. A. Leg 1; B. Leg 2; C. Leg 3; D. Leg 4; E. Tip of Leg 5. Scales: $0.2 \mathrm{~mm}$ in A-D; $0.1 \mathrm{~mm}$ in $\mathrm{E}$. 
Family Dichelesthiidae Kabata, 1979

Anthosoma crassum (Abildgaard, 1794)

Material examined. Three ovigerous females attached to buccal cavity of Carcharodon carcharias (Linnaeus) caughted off Todohokke, Hokkaido on 31 May 1985.

Remarks

This is one of the few widely distributed species of parasitic copepods having been reported from many parts of the world. Due to its unusually wide distribution, it has been described many times in the past. In Japan, Shiino (1955b) reported it from sharks landed in Kannoura, Koti; Kesennuma, Miyagi; Tyosi, Chiba; and Owase, Mie. However, this is the first record from Hokkaido.

Family Hatschekiidae Kabata, 1979

Hatschekia conifera Yamaguti, 1939

Material examined. Three ovigerous females from gills of Brama japonica Hilgendorf caught off Kushiro on 6 November 1984.

Remarks

This species was first reported by Yamaguti (1939) based on 8 specimens recovered from a Stromateoides (=Pampus) argentus (Euphrasen) kept in the "Marine Biological Laboratory of the Imperial University of Kyoto". According to Jones (1985), this species is widely distributed in the Pacific, being recorded from Canada, Chile, and New Zealand, in addition to Japan. If Kabata's (1981) relegation of Hatschekia acuta Barnard to the synonymy of the present species is correct, then, the distribution of $H$. conifer extends to South Africa.

\section{Family Pennellidae Burmeister, 1835}

\section{Haemobaphes pannosus Kabata, 1979}

(Figs. 12-13)

Material examined. All attached to gill arches of hosts: 1 female on Spirinchus lanceolatus (Hikita) caught off Kushiro on 1 December 1983; 6 females from Liparis sp. caught off Kushiro, Hokkaido on 29 September 1984; 42 females on Liparis agassizii (Putnam) collected off Taejin (100 km north of Kangreung) on 27 December 1986; and 1 female on Crystallias matsushimae Jordan \& Snyder caught off Sokcho (60 km north of Kangreung) on 28 June 1992.

Remarks

This is the least known member of Haemobaphes. It is so far known only from one report made by Kabata (1979) based on the specimens parasitic on Pholidopus dybowskii caught in the Kermadec Islands in the South Pacific. Our specimens from the Sea of Japan and off Kushiro, Hokkaido differs somewhat from Kabata's original description in the shape of the cephalothorax (Fig. 12A-H) and its processes. However, we do not consider the differences are species significant, as the three specimens shown in Fig. 12 (B,E;C,F and D,G), these body processes are variable between specimens.

The appendages of $H$. cyclopterina (Fabricius) have been well described by Gooding \& Humes (1963). To this species $H$. pannosus shows the closest resemblance in the general structure of the cephalothorax. Since, in general, the appendages of congeners in the pennellids do not show much difference, it is not supprising to see that the appendages of $H$. pannosus shown in Figs. 13A-I are almost identical with those given by Gooding \& Humes 


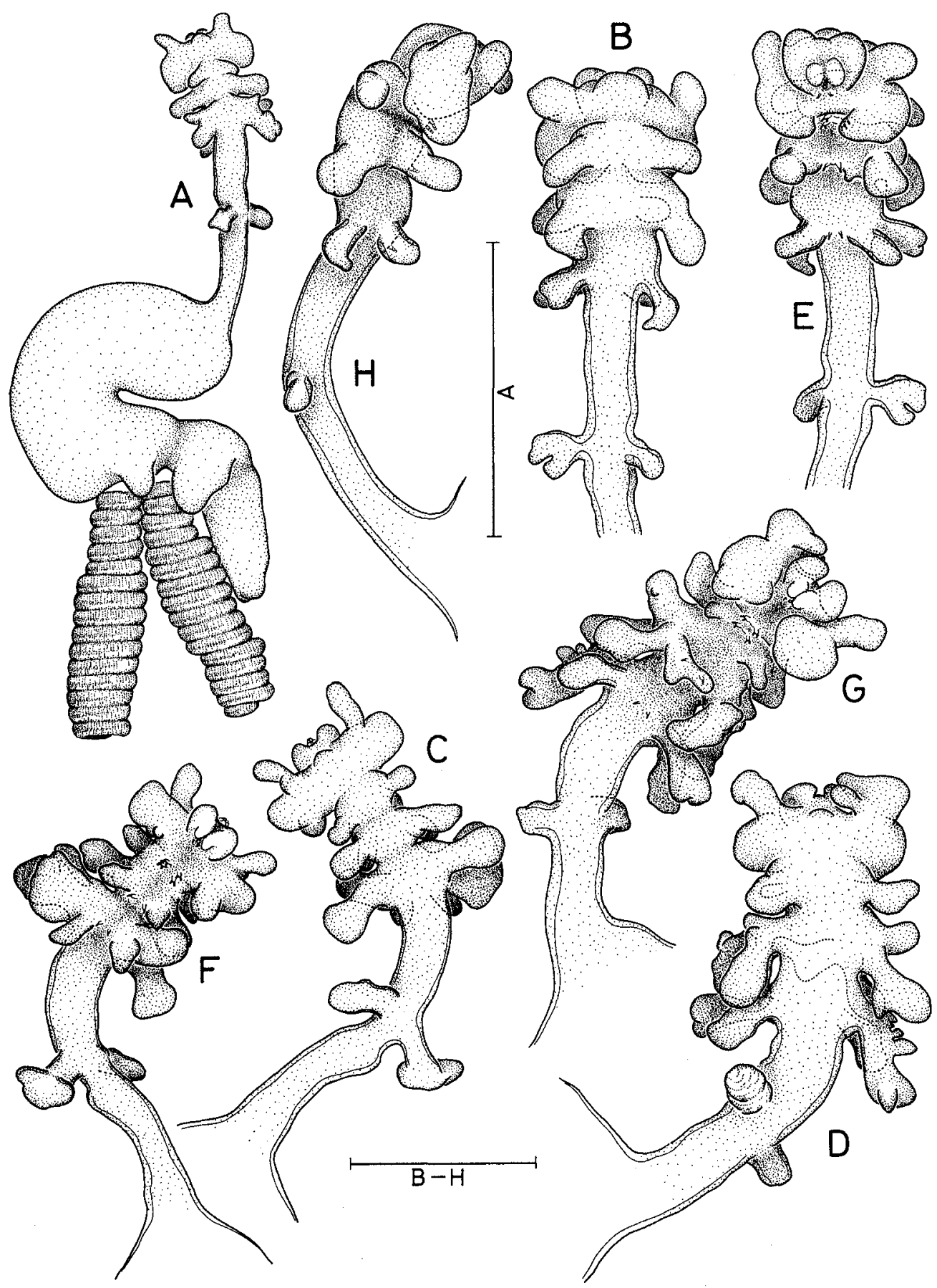

Fig. 12. Haemobaphes pannosus Kabata, female. A. Habitus of specimen 1, dorsal, with cephalothorax twisted dorsally; B, C and D. Cephalothorax of specimen 2, 3 and 4, dorsal; E, F and G. Same, ventral. Scales: $10 \mathrm{~mm}$ in $A ; 3 \mathrm{~mm}$ in $B-H$. 


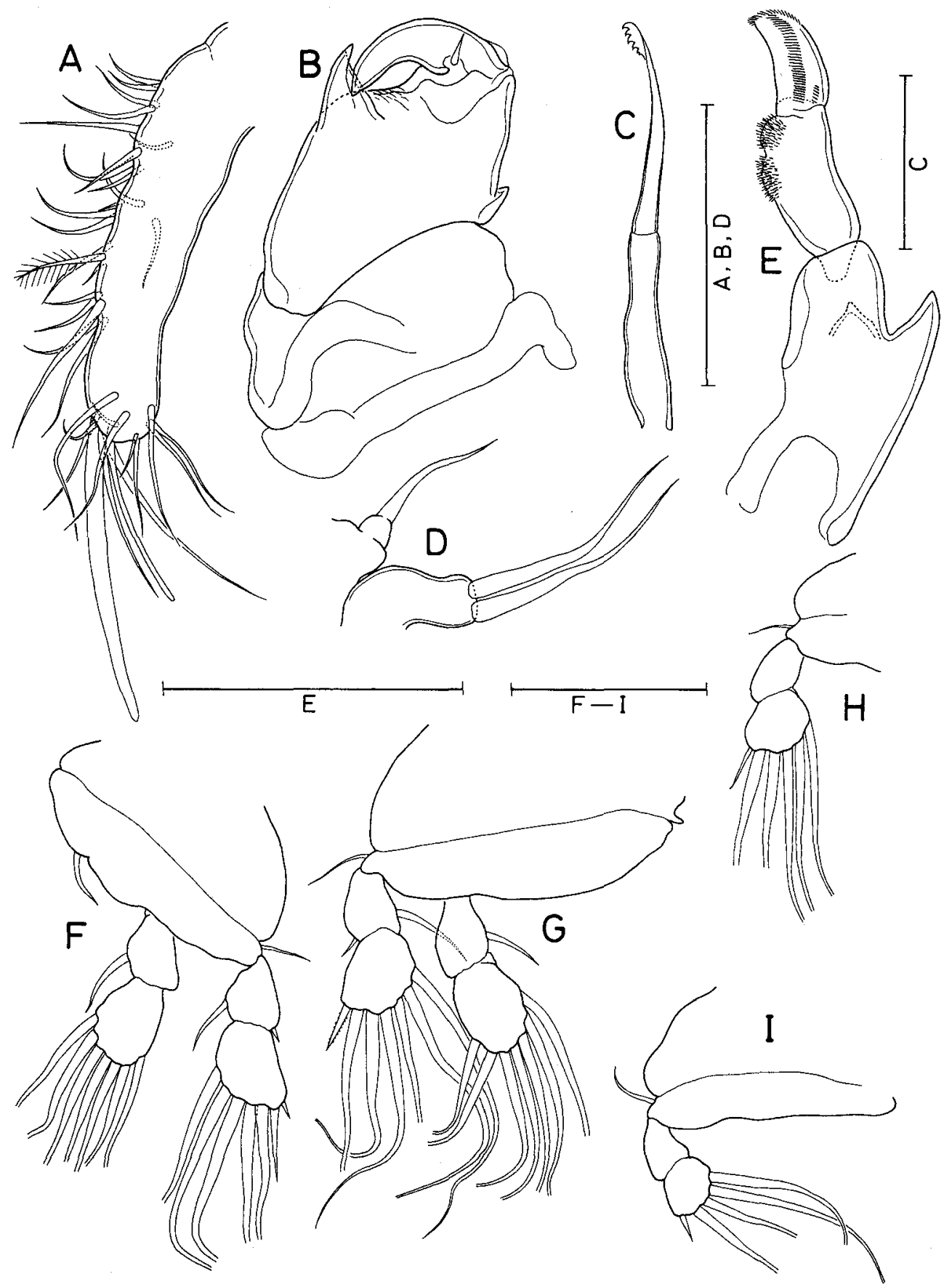

Fig. 13. Haemobaphes pannosus Kabata, female. A. Antennule; B. Antenna; C. Mandible; D. Maxillule; E. Maxilla; F. Leg 1; G. Leg 2; H. Leg 3; I. Leg 4. Scales: $0.1 \mathrm{~mm}$ in A, B, D; $0.05 \mathrm{~mm}$ in C; $0.1 \mathrm{~mm}$ in $\mathrm{E}, \mathrm{F}-\mathrm{I}$. 
for H. cyclopterina.

Markevitch \& Titar (1978) reported the occurrence of $H$. cyclopterina in the Sea of Okhotsk and Bering Sea. However, according to Kabata (1967), H. cyclopterina is strictly a parasite of the North Atlantic, thus, what used to be called $H$. cyclopterina in the North Pacific are, in all probability, a misidentification of the present species.

\section{Haemobaphes diceraus Wilson, 1917}

(Figs. 14-15)

Material examined. All attaches to gill arches: 3 from Gadus macrocephalus Tilesius caught off Kushiro on 29 September 1984; 6 from Theragra chalcogramma (Pallas) caught off Kushiro on 29 September 1984; 7 from $T$. chalcogramma caught off Mukho, Korea (40 km south of Kangreung) on 10 March 1988; 1 from G. macrocephalus caught off Kangreung on 29 February 1992.

Remarks

There is not a slightest doubt that our specimens of Haemobaphes obtained from the walleye pollacks caught off Mukho, Korea are the same species of parasite reported by Yamaguti (1939) from the same host fish landed at Baiye, Toyama, Japan. Yamaguti's (1939) major contention to call it as a new species, $H$. theragrae, was "the thoracic segments being entirely undifferentiated". However, as shown in Fig. 14D and E, although the thoracic segments are not clearly differentiated, they are still discernible. And, a close comparison of our specimens with the redescription of $H$. diceraus given by Kabata (1967) shows that there is no significant difference between them. Thus, we concur with Grabda (1975) that Haemobaphes theragrae Yamaguti, 1939 should be relegated to the synonym of $H$. diceraus Wilson, 1917. The type locality of this species is Hakodate, Hokkaido (Wilson, 1917). Although Markevtch \& Titar (1978) recorded $H$. diceraus from the Soviet Far East (including the Sea of Japan, Sea of Okhotsk and Bering Sea), no host was given.

This species can be easily separated from $H$. pannosus by having greatly elongated cephalothorax and lacking anterior processes of the cephalothorax. As far as the appendages (Figs. 14F-I, 15-E) are concerned, there is no significant differences between the two.

Family Lernaeopodidae Olsson, 1869

\section{Clavella adunca (Strøm, 1762)}

Material examined. One ovigerous female on inner surface of operculum of Malacocottus zonurus Bean collected from Bering Sea (date unknown) and kept in Faculty of Fisheries, Hokkaido University; 2 ovigerous females on gill arch and dorsal fin of a Eleginus gracilis (Tilesius) caught off Kushiro on 14 October 1981.

Remarks

Although Markevitch and Titar (1978) recorded this species from the Bering Sea, no host was mentioned. This parasite has been recorded from many species of gadoids from the North Atlantic and North Pacific; however, this is the first time to report it from a sculpin, Malacocottus zonurus. For a complete list of hosts and a good description of this species, see Kabata (1979).

\section{Nectobrachia iceli, new species}

(Fig. 16)

Material examined. Three ovigerous and 2 juvenile females attached to gill filaments of 2 Icelus ochotensis Schmidt collected from Sea of Okhotsk (date unknown) and kept in Faculty of Fisheries, Hokkaido University. Holotype and 3 paratypes deposited in the U.S. National 


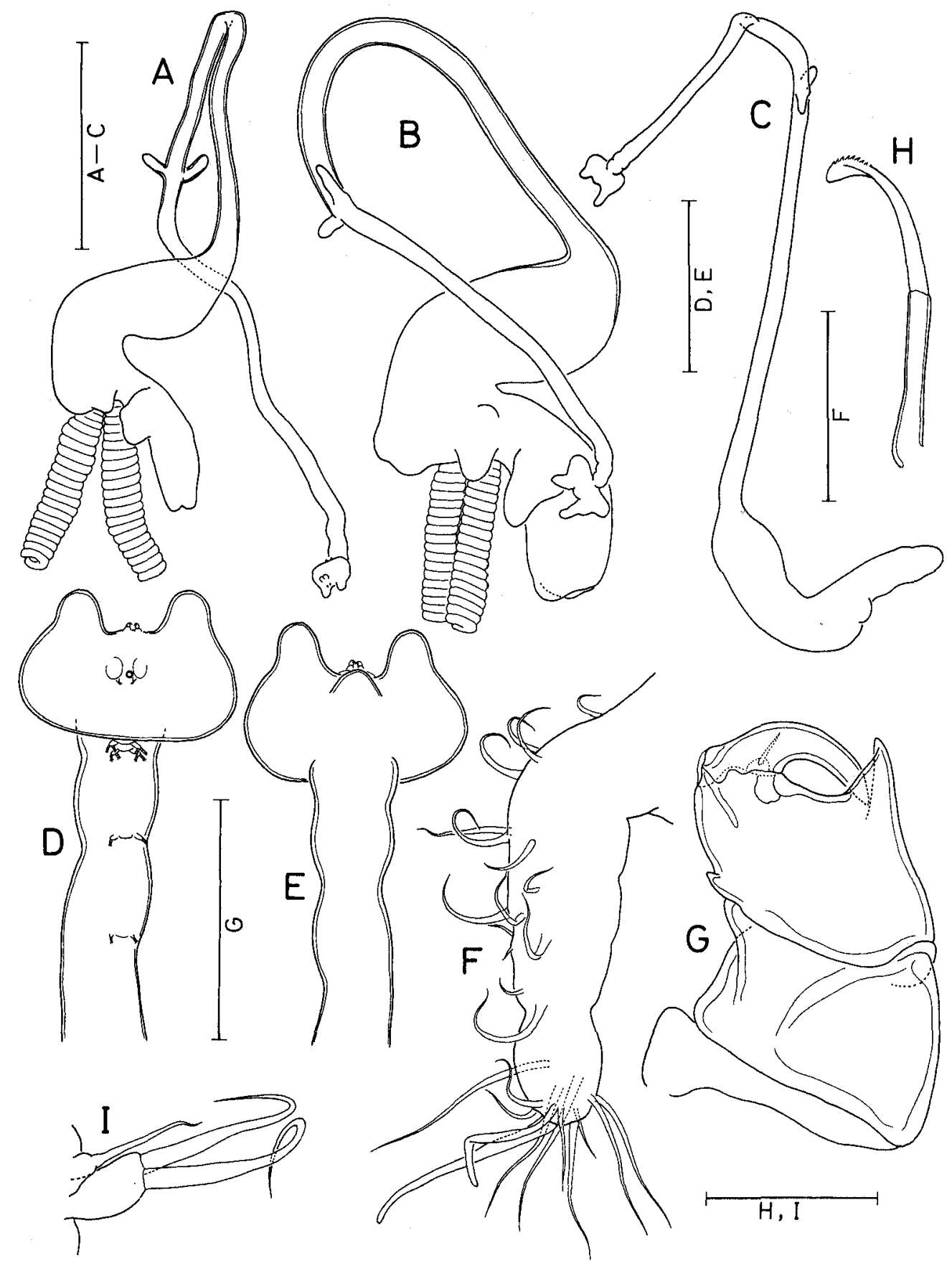

Fig. 14. Haemobaphes diceraus Wilson, female. A. Habitus, lateral, with cephalothorax twisted ventrally; B. Habitus of other specimen; with cephalothorax twisted dorsally; C. Habitus of juvenile, lateral, with cephalothorax twisted dorsally; D. Cephalothorax, ventral; E. Same, dorsal; F. Antennule; G. Antenna; H. Mandible; I. Maxillule. Scales: $10 \mathrm{~mm}$ in A-C; $2 \mathrm{~mm}$ in D, E; $0.05 \mathrm{~mm}$ in F, H, I; $0.1 \mathrm{~mm}$ in $\mathrm{G}$. 
Museum of Natural History, Smithsonian Institution, Washington, D.C.

Female

Body (Fig. 16A) with bulbous trunk carrying small, conical cephalothorax (Fig. 16C) on anterior margin and protruded anal region on posterior margin. Trunk of juvenile individual (Fig. 16B) not bulbouds but rather rectangular. Antennule (Fig. 16D) short, tipped with 5 setae and 1 aesthete. Antenna (Fig. 16E) with exopod smaller than endopod, which bears spinules and 2 setae; exopod indistinctly 2 -segmented, both segments with denticles on mediodistal corner, terminal segment tipped with 3 elements. Mandible (Fig. 16F) armed with 9 (5 large +4 small) teeth. Maxillule (Fig. 16G) tipped with two setae. Maxilla (Fig. 16H) longer than trunk and pointed distally. Maxilliped (Fig. 16I) 2-segmented, attaching to a large protuberance; corpus carrying a myxal spine and subchela with 1 seta at midlength, 1 terminal set and 1 claw.

Male. Unknown.

Remarks

The new species differs from the type-species, $N$. indivisa Fraser, in having a bulbous trunk with protruded anal region. Its arm (maxilla) is also different in having pointed (instead of greatly swollen) tip. Besides, they occur on different group of hosts, while $N$. indivisa is known from faltfishes (Yü \& Wu, $1932 \mathrm{Gusev,} 1951$; Kabata, 1970), N. iceli is found

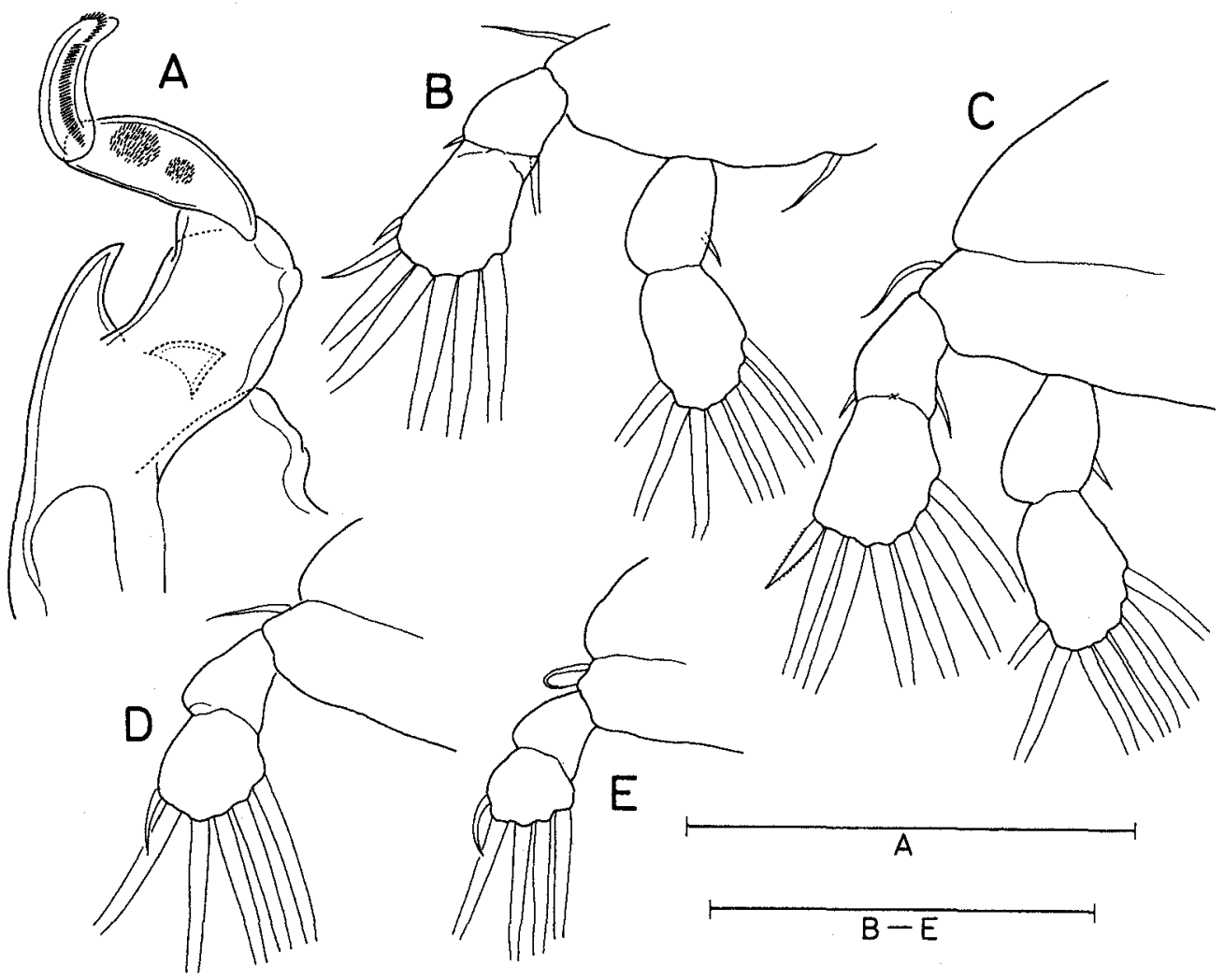

Fig. 15. Haemobaphes diceraus Wilson, female. A. Maxilla; B. Leg 1; C. Leg 2; D. Leg 3; E. Leg 4. Scales: $0.1 \mathrm{~mm}$ in A, B-E. 


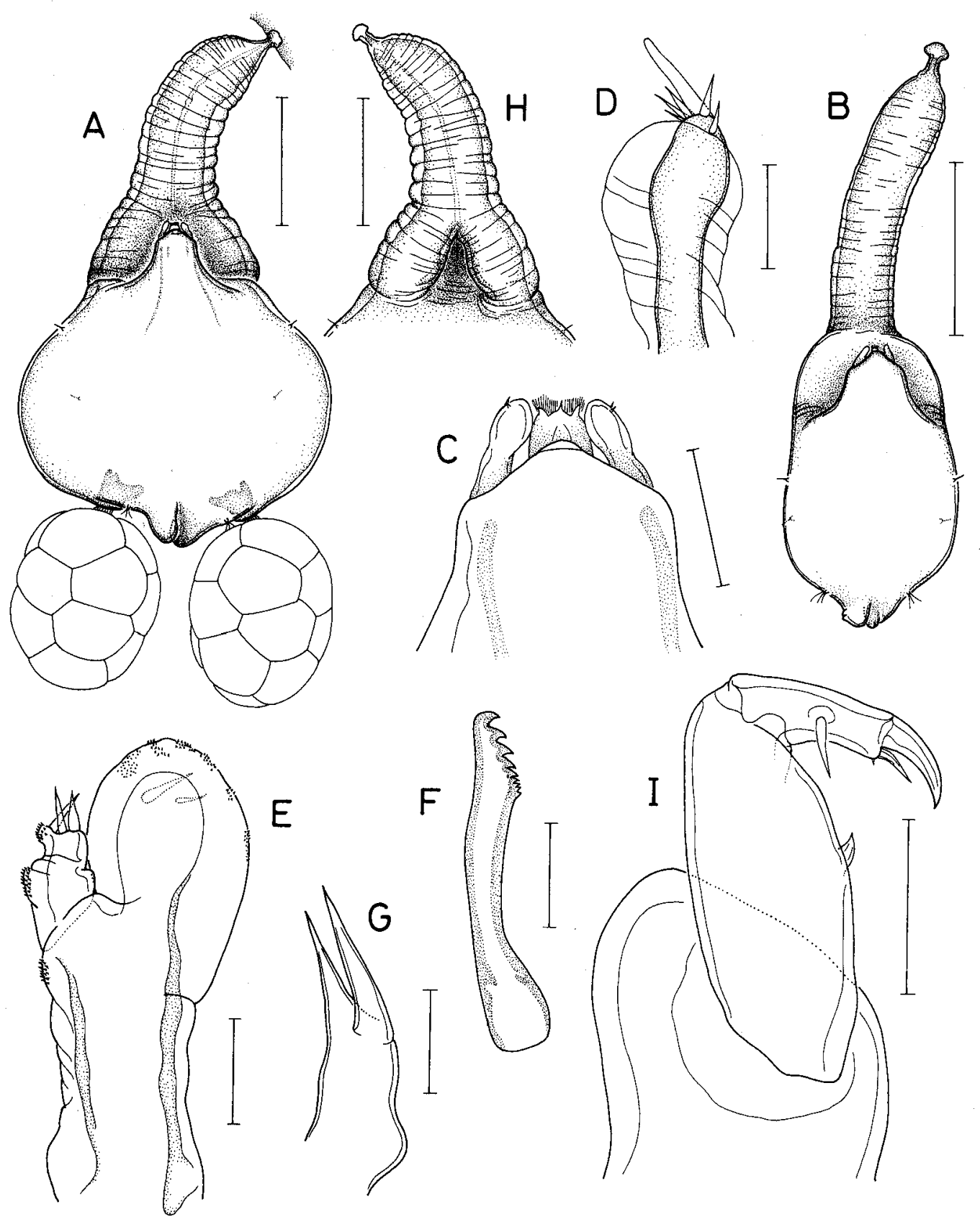

Fig. 16. Nectobrachia iceli, new species, female. A. Habitus, dorsal; B. Habitus of juvenile, dorsal; C. Cephalothorax (= head), dorsal; D. Antennule; E. Antenna; G. Maxillule; H. Maxilla (= arm), posterior; I. Maxilliped. Scales: $0.5 \mathrm{~mm}$ in A, B, H; $0.1 \mathrm{~mm}$ in C; $0.01 \mathrm{~mm}$ in D-G; $0.05 \mathrm{~mm}$ in I. 


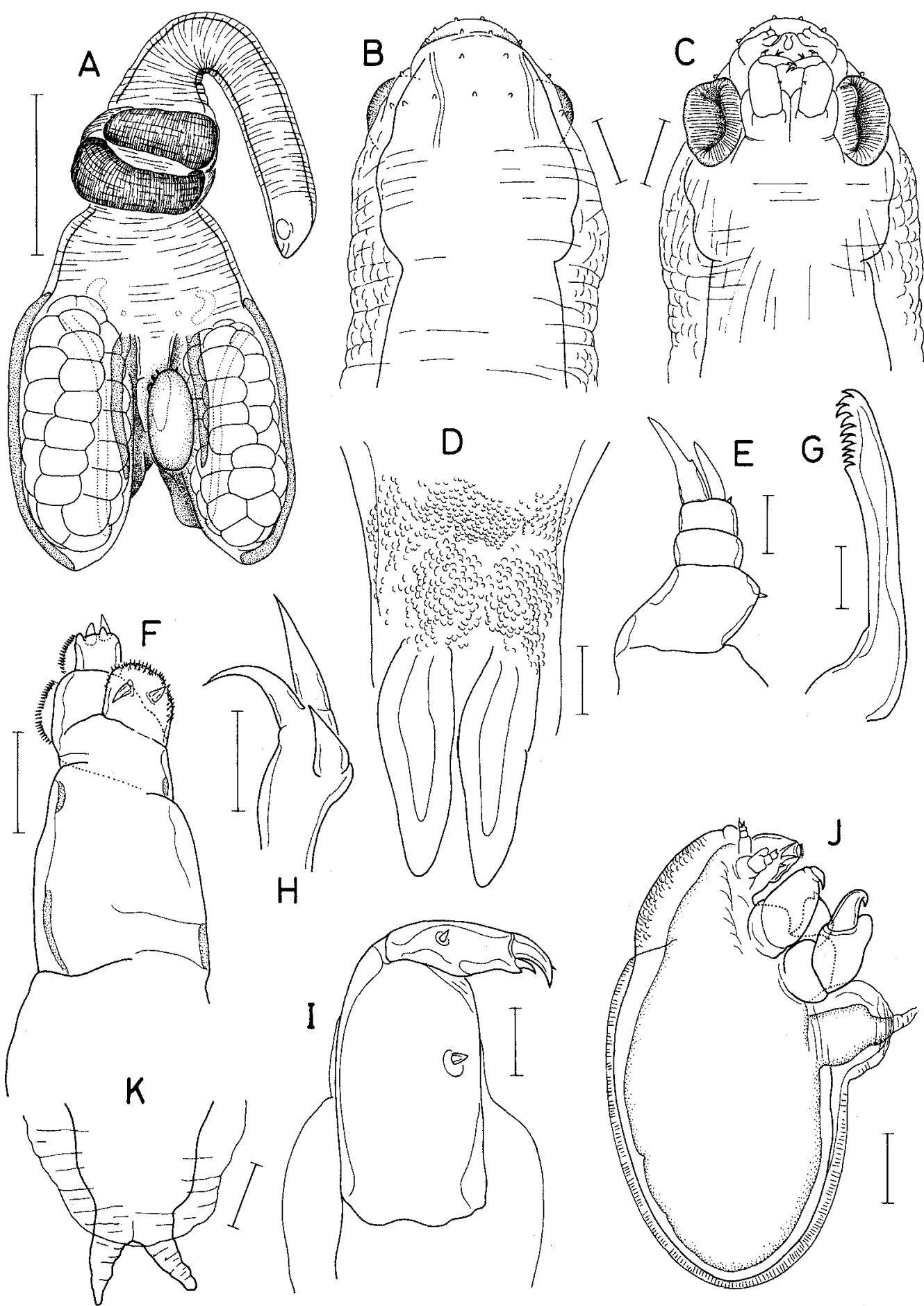

Fig. 17. Naobranchia occidentalis Wilson. Female: A. Habitus, ventral; B. Head, dorsal; C. Same, ventral; D. Caudal rami; E. Antennule; F. Antenna; G. Mandible; H. Maxillule; I. Maxilliped. Male: J. Habitus, lateral. Scales: $1 \mathrm{~mm}$ in A; $0.1 \mathrm{~mm}$ in B-D, J; $0.01 \mathrm{~mm}$ in E, G; $0.02 \mathrm{~mm}$ in F, H, I; 0.05 $\mathrm{mm}$ in $\mathrm{K}$. 


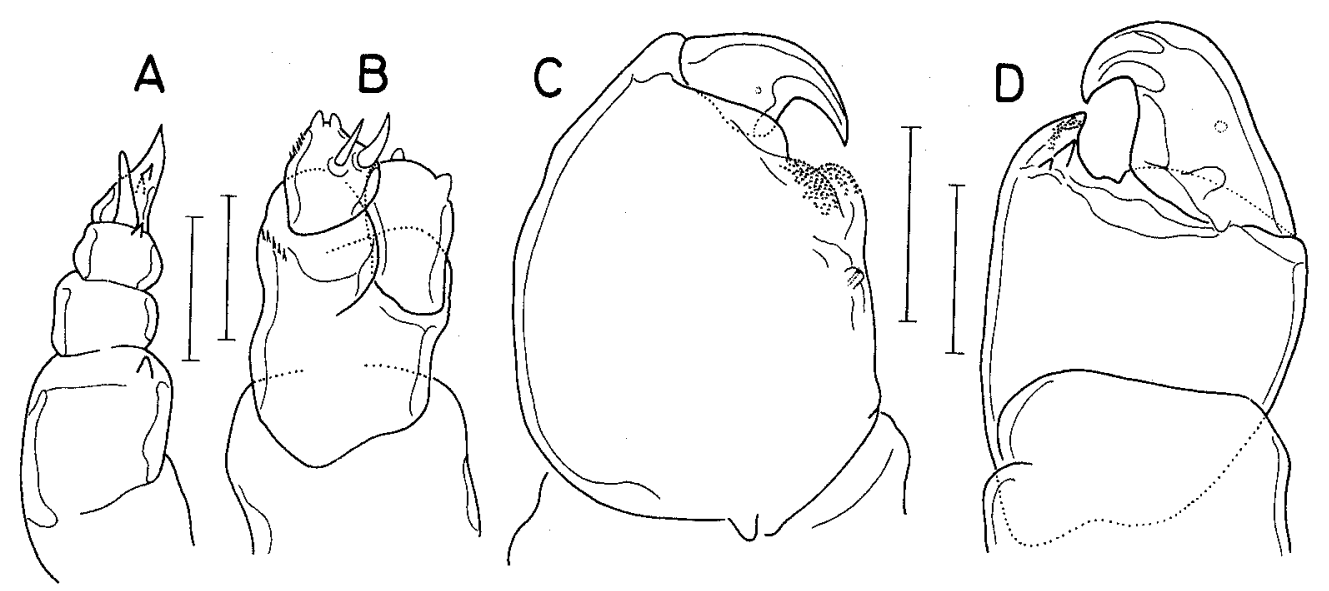

Fig. 18. Naobranchia occidentalis Wilson, male. A. Antennule; B. Antenna; C. Maxilla; D. Maxilliped. Scales: $0.02 \mathrm{~mm}$ in A, B; $0.05 \mathrm{~mm}$ in C, D.

on the sculpin. Hansen's (1923) Nectobrachia producta, parasitic on the grenadier in the North Atlantic, is distinguishable from the new species in having a large cephalothorax and extremely long arm (twice the length of trunk).

\section{Pseudocharopinus markewitschi (Gusev, 1951)}

Material examined. One ovigerous female on fin of Raja pulchra Liu caught off Kushiro on 11 March 1983.

\section{Remarks}

This species was described by Gusev (1951) from the skates in the Sea of Japan and placed in the genus "Charopinus". The specimen from Hokkaido fits well with the description given by Gusev (1951).

Family Naobranchiidae Yamaguti, 1939

\section{Naobranchia occidentalis Wilson, 1915}

(Figs. 17-18)

Material examined. Three females (with one carrying a male) attached to gill filaments of 2 Icelus canaliculatus Gilbert collected from Hokkaido (date unknown); 2 females on gill filament of Icelus euryops Bean collected from Bering Sea (date unknown) and kept in Faculty of Fisheries, Hokkaido University.

Female

Body (Fig. 17A) with a cylindrical, long cephalothorax and a stout, subtriangular trunk. Head (Fig. 17B,C) carrying small, hyaline tubercles on dorsal surface and a pair of large, corrugated spheres ventrally just lateral to maxillipeds. Abdomen (Fig. 17D) long and slender, bearing a pair of unarmed caudal rami. Antennule (Fig. 17E) 3-segmented, armed with a small seta on proximal segment and 3 extremely unequal elements on distal segment. Antenna (Fig. 17F) biramous, with small endopod bearing 2 setae and 2-segmented exopod tipped with 4 obtuse elements. Mandible (Fig. 17G) armed with 9 teeth. Maxillule (Fig. 17H) biramous: exopod a papilla tipped with a seta and endopod 2 papillae each with a seta. 
Maxillae (Fig. 17A) a pair of long, ribbon-like bands with one posterior to the other. Maxilliped (Fig. 17I) with corpus bearing a small myxal spine and subchela armed with 1 seta at midlength and tipped with 1 small seta and 1 claw.

Male

Body (Fig. 17J) small, plump and suboval, measuring $690 \times 295 \mu \mathrm{m}$. Abdomen attached to midventral portion of body. Caudal ramus (Fig. 17K) digitiform. Antennule (Fig. 18A) and antenna (Fig. 18B) as in female but slightly different in armature. Mandible and maxillule without sexual dimorphism. Maxilla (Fig. 18C) 2-segmented; proximal segment robust, with patches of denticles and small tubercle on medial surface; distal segment a stout, curved claw. Maxilliped (Fig. 18D) 3-segmented; first segment small and unarmed; second segment with mediodistal corner protruded into a sharp process and carrying 2 denticles; and distal segment a stout, curved claw.

Remarks

$N$. occidentalis is known only from codfishes, rockfishes and flatfishes in the Sea of Okhotsk, Bering Sea and off the west coast of North America (see Markevitch, 1956; Yamaguti, 1963 and Kabata, 1988). This is the first time to report it from the sculpins.

\section{Acknowledgements}

We are indebted to Dr. Kazuya Nagasawa at the National Research Institute of Far Seas Fisheries in Shimizu for placing at our disposal his valuable collections of parasitic copepods from fishes of the western North Pacific. The completion of this work was partially funded by California State University, Long Beach.

\section{References}

Atria, G. 1980. Chondracanthidae en Chile, con descripcion de una especie nueva: Chondracanthus yanezi n. sp. (Copepoda, Cyclopoidea). Bol. Mus. Nac. Hist. Nat. Chile, 37: 303-308.

Cressey, R.F. 1967a. Genus Gloiopotes and a new species with notes on host specificity and intraspecific variation (Copepoda: Caligoida). Proc. U.S. Nat. Mus., 122(3600): 1- 22.

Cressey, R.F. 1967b. Revision of the family Pandaridae (Copepoda: Caligoida). Proc. U.S. Nat. Mus., 121(3570): 1-133.

Gooding, R.U. \& Humes, A.G. 1963. External anatomy of the female Haemobaphes cyclopterina, a copepod parasite of marine fishes. J. Parasit., 49(4): 663-677.

Grabda, J. 1975. Observations on the localization and pathogenicity of Haemobaphes diceraus Wilson, 1917 (Copepoda: Lernaeoceridae) in the gills of Theragra chalcogramma (Pallas). Acta Ichthyol. Piscat., 5(2): 13-23.

Gusev, A.V. 1951. Paraziticheskie Copepoda s nekotorykh morskikhryd. Parazit. Sb., 13: 394-463.

Hansen, H.J. 1923. Crustacea Copepoda, II. Copepoda parasita and hemiparasita. The Danish Ingolf-Expedition, 3(7): 1-92.

Hewitt, G.C. 1964. A redescription of Gloiopotes huttoni (Thomson, 1899), with a key to the species of the genus. Trans. R. Soc. N. Zeal. Zool., 5(8): 85-96.

Ho, J.S. 1982. Copepod parasites of Psychrolutes (Pisces: Scorpaeniformes) from deep water in the eastern Pacific. Parasit., 85: 451-458.

Ho, J.S. 1991. Redescription of Chondracanthus zei Delaroche (Copepoda, Poedilostomatoida) parasitic on Zeus faber L. in the Sea of Japan, with preliminary review of the genus. Rep. Sado Mar. Biol. Sta. Niigata U., 21: 49-79.

Ho, J.S. \& Kim, I.H. 1995. Acanthochondria (Copepoda: Chondracanthidae) parasitic on fishes of Sado Island in the Sea of Japan, with a preliminary review of the genus. Rep. Sado Mar. Biol. Sta. Niigata U., 25: 45-67. 
Jones, J.B. 1985. A revision of Hatschekia Poche, 1902 (Copepoda: Hatschekiidae), parasitic on marine fishes. N. Z. J. Zool., 12: 213-271.

Kabata, Z. 1967. The genus Haemobaphes (Copepoda: Lernaeoceridae) in the waters of British Columbia. Can. J. Zool., 45: 853-875.

Kabata, Z. 1968. Somie Chondracanthidae (Copepoda) from fishes of British Columbia. J. Fish. Res. Bd. Can., 25: 321-345.

Kabata, Z. 1970. Some Lernaeopodidae (Copepoda) from fishes of British Columbia. J. Fish. Res. Bd. Can., 27: 865-885.

Kabata, Z. 1979a. Parasitic Copepoda of British fishes. The Ray Society, London. 468 pp.

Kabata, Z. 1979b. One poorly known and two new species of the parasitic Copepoda from the collection of the Zoological Institute in Leningrad. Parasitologie, 13(1): 43-49.

Kabata, Z. 1981. Relegation of Hatschekia acuta Barnard, 1948 to synonym with Hatschekia conifera Yamaguti, 1939. (Copepoda, Siphonostomatoida). Can. J. Zool., 59(11): 2080-2084.

Kabata, Z. 1984. A contribution to the knowledge of Chondracanthidae (Copepoda: Poecilostomatoida) parasitic on fishes of British columbia. Can. J. Zool., 62: 1703-1713.

Kabata, Z. 1988. Copepoda and Branchiura. In: Guide to the Parasites of Fishes of Canada, Part II- Crustacea. Can. Spec. Publ. Fish. \& Aquat. Sci., 101: 4-127.

Kabata, Z. \& Gusev, A.V. 1966. Parasitic Copepoda of fishes from the collection of the Zoological Institute in Leningrad. J. Linn. Soc. (Zool.), 46: 155-507.

Kazachenko, V.N. 1995. A new species of parasitic copepods of the genus Haemobaphes (Crustacea: Copepoda: Pennellidae) from fishes of the genus Liparis (Cottoidei: Liparidae) of the Pacific Ocean. Parasitologia, 29(2): 117-126.

Lewis, A.G. 1967. Copepod crustaceans parasitic on teleost fishes of the Hawaiian Islands. Proc. U. S. Nat. Mus., 121(3574): 1-204.

Markevich, A.P. 1956. Paraziticheskie Veslonogie Ryb SSSR. Akad. Nauk. Kiev, 259 pp.

Markevich, A.P. \& Titar, V.M. 1978. Copepod parasites of marine fishes from the Soviet Far East. Proc. 4th Internat. Cong. Parasit. Sec. H, pp. 38-39.

Nagasawa, K. 1984. Occurrence of Pennella sp. (Copepoda: Pennellidae) on the saury, Cololabis saira, in Japanese and central North Pacific waters in 1983. J. Hokk. Fish. Exp. Sta., 41(6): 221236.

Nagasawa, K. 1985. Comparison of the infection levels of Lepeophtheirus salmonis (Copepoda) on Chum salmon captured by two methods. Jap. J. Ichthyol., 32(3): 368-370.

Nagasawa, K. \& Maruyama, S. 1987. Occurrence and effects of Haemobaphes diceraus (Copepoda: Pennellidae) on brown sole Limanda herzensteini off the Okhotsk coast of Hokkaido. Bull. Jap. Soc. Sci. Fish., 53(6): 991-994.

Pillai, N.K. 1985. Fauna of India. Parasitic Copepoda of Marine Fishes. Zoological Survey of India, $900 \mathrm{pp}$.

Shiino, S.M. 1954a. On the parasitic copepod, Lepeophtheirus watanabei n. sp., found on the fish, Myxocephalus raninus J. \& S. Bull. Jap. Soc. Sci. Fish., 20(2): 96-100.

Shiino, S.M. 1954b. Copepods parasitic on Japanese fishes. 4. The family Euryphoridae. Rep. Fac. Fish. Pref. Univ. Mie, 1(3): 273-290.

Shiino, S.M. 1954c. Copepods parasitic on Japanese fishes. 5. Five species of the family Pandaridae. Rep. Fac. Fish. Pref. Univ. Mie, 1(3): 291-332.

Shiino, S.M. 1955a. Copepods parasitic on Japanese fishes, 9. Family Chondracanthidae, subfamily Chondracanthinae. Rep. Fac. Fish. Pref. Univ. Mie, 2(1): 70-111.

Shiino, S.M. 1955b. Copepods parasitic on Japanese fishes, 8. The Anthosomatidae. Rep. Fac. Fish. Pref. Univ. Mie, 2(1): 50-69.

Shiino, S.M. 1957. Copepods parasitic on Japanese fishes, 13. Parasitic copepods collected off Kesennuma, Miyagi Prefecture. Rep. Fac. Fish. Pref. Univ. Mie, 2: 359-376.

Shiino, S.M. 1959a. Revision der auf Goldmakrele, Coryphaena hippurus L., schmarotzenden Caligidenarten. Ann. Rep. Pref. Univ. Mie, Sec. 2, Nat. Sci., 3(1): 1-34.

Shiino, S.M. 1959b. Ostpazifische parasitierende Copepoden. Rep. Fac. Fish. Pref. Univ. Mie, 3(2): 267-333. 
Shiino, S.M. 1963. Parasitic copepods of the eastern Pacific fishes. 3. Echthrogaleus pellucidus sp. nov. Rep. Fac. Fish. Pref. Univ. Mie, 4(3): 357-368.

Wilson, C.B. 1907. North American parasitic copepods belonging to the family Caligidae. Part. 3 and 4. A revision of the Pandarinae and Cecropinae. Proc. U. S. Nat. Mus., 33(1573): 326-490.

Wilson, C.B. 1917. North American parasitic copepods belonging to Lernaeidae, with a revision of the entire family. Proc. U. S. Nat. Mus., 53(2194): 1-150.

Wilson, C.B. 1919. North American parasitic copepods belonging to the new family Sphyriidae. Proc. U. S. Nat. Mus., 55(2286): 549-604.

Yamaguti, S. 1936. Parasitic copepods from fishes of Japan. Pt. 3. Caligoida II. Publ. by author, Japan, $21 \mathrm{pp}$.

Yamaguti, S. 1939. Parasitic copepods from fishes of Japan, Pt. 5. Caligoida, III. Vol, jub. Prof. Sadao Yoshida, 2: 443-487.

Yamaguti, S. 1963. Parasitic Copepoda and Branchiura of Fishes. Interscience Publications, New York, London and Sydney. 1104 pp.

Yü, S.C. \& Wu, H.W. 1932. Parasitic copepods on the flat-fishes from China. Bull. Fan Mem. Inst. Biol., 3(4): 55-74. 